Canadian

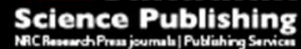

Canadian Journal of Microbiology Revue canadienne de de microbiologie

\title{
Entry, infection, replication and egress of human Polyomaviruses: an update.
}

\begin{tabular}{|r|l|}
\hline Journal: & Canadian Journal of Microbiology \\
\hline Manuscript ID & cjm-2016-0519.R1 \\
\hline Manuscript Type: & Review \\
\hline Date Submitted by the Author: & 13 -Oct-2016 \\
\hline Complete List of Authors: & $\begin{array}{l}\text { Bhattacharjee, Soumen; University of North Bengal, Zoology } \\
\text { Chattaraj, Sutanuka; University of North Bengal, Zoology }\end{array}$ \\
\hline Keyword: & Polyomavirus, infection, receptor, co-receptor \\
\hline & \\
\hline
\end{tabular}




\section{TITLE PAGE}

Title: Entry, infection, replication and egress of human Polyomaviruses: an update.

\section{Name of the Authors:}

1. Soumen Bhattacharjee (Corresponding Author)

Associate Professor

Cell and Molecular Biology Laboratory, Department of Zoology,

University of North Bengal, Raja Rammohunpur, P.O. North Bengal University, Siliguri, District Darjeeling, West Bengal, PIN- 734 013, INDIA.

\section{Sutanuka Chattaraj}

Research Scholar

Cell and Molecular Biology Laboratory, Department of Zoology,

University of North Bengal, Raja Rammohunpur, P.O. North Bengal University, Siliguri, District Darjeeling, West Bengal, PIN- 734 013, INDIA.

Affiliation and Address of the Corresponding Author:

Cell and Molecular Biology Laboratory

Department of Zoology

University of North Bengal

Raja Rammohunpur

P.O. North Bengal University

Siliguri

District - Darjeeling

West Bengal

PIN - 734013

INDIA.

E-mail: soumenb123@rediffmail.com, sbhnbu@gmail.com

Telephone: +91-0353-2776353 (O)/ +919474674013 (M)

Fax: +91-0353-2699001 


\begin{abstract}
Polyomaviruses (PyVs), belonging to the family Polyomaviridae, are a group of small, nonenveloped, double-stranded, circular DNA viruses, widely distributed in the vertebrates. Polyomaviruses cause no apparent disease in adult laboratory mice, but cause a wide variety of tumors when artificially inoculated into neonates or semi-permissive animals. A few human polyomaviruses, such as BK, JC, Merkel cell polyomavirus, have been unequivocally linked to pathogenesis under conditions of immunosuppression. Infection is thought to occur early in life which persists for the lifespan of the host. Over evolutionary time scales, it appears that polyomaviruses have slowly co-evolved with specific host animal lineages. Host cell surface glycoproteins and glycolipds seem to play a decisive role in the infectious entry, and in channeling virions to specific intracellular membrane-bound compartments and ultimately to the nucleus, where the genomes are replicated and packaged for release. Targeting of the infecting virion or viral genome to this multiplication site is therefore an essential process in the productive viral infection as well as in latent infection and transformation. This review summarizes the major findings related to the characterization of the nature of PyV-host protein interactions and their outcomes in host cell invasion.
\end{abstract}

Key Words: Polyomavirus, infection, receptor, co-receptor 


\section{Introduction}

Polyomaviruses (PyVs) are non-enveloped, icosahedral, double-stranded small DNA viruses that were among the first mammalian viruses to be analyzed molecularly. Comparison of viral genomes, especially the viral origin of replication, indicates that after evolving from a common ancestor this group may have diverged with their natural hosts (Soeda et al. 1980; Buck et al. 2016). Thirteen human polyomaviruses have been identified to date. BK virus (BKPyV) was the first and JC virus (JCPyV) was the second in the group to be identified and were named after the initials of the patients from whom they were first isolated (Gardner et al. 1971; Padgett et al. 1971). Human polyomavirus KI (KIPyV) and WU (WUPyV) were named after institutions where they were first reported (Allander et al. 2007; Gaynor et al. 2007). Merkel cell polyomavirus (MCPyV) and trichodysplasia spinulosa (TS) polyomavirus (TSPyV) were named based on their discovery in Merkel cell carcinoma (MCC, a rare form of skin cancer) (Feng et al. 2008) and in TS, a rare skin condition (Meijden et al. 2010). HPyV6 and HPyV7 were detected in human skin (Schowalter et al. 2010) and HPyV9 in both serum and skin (Scuda et al. 2011), and were named according to their order of discovery. Malawi polyomavirus (MWPyV) (Siebrasse et al. 2012), also known as HPyV10 (Buck et al. 2012) or Mexico polyomavirus (Yu et al. 2012), was detected in stool and skin samples roughly simultaneous. Saint Louis polyomavirus (STLPyV) was detected in the clinical stool specimen (Lim et al. 2013), HPyV12 in human liver tissue (Korup et al. 2013), and New Jersey Polyomavirus (NJPyV) in endothelium of a muscle biopsy from a pancreatic transplant recipient (Mishra et al. 2014).

Classical viral infection in the host cell is initiated by interactions between viral capsid or envelope proteins and cell surface receptors. Internalization of the virion occurs either by fusion of the envelope and the plasma membrane or via endocytic pathways that lead to escape of the 
virion from an endocytic or other vesicular compartment into the cytosol (Smith and Helenius 2004; Marsh and Helenius 2006). Attachment to cellular receptors can directly trigger conformational changes in virus surface structures or can activate specific signaling pathways that facilitate viral entry. Replication of the viral genome, viral protein synthesis, assembly of the viral particles and their release from the cell use the host cellular machinery. The release of the virion occurs via budding followed by exocytosis or cell lysis (Marsh and Helenius 2006). The release of non-enveloped viruses usually occurs through cell lysis, but in some cases, they may escape either by some secretary mechanisms (Altenburg et al. 1980), or may use cellular autophagy pathways for exit (Jackson et al. 2005). Recent evidences indicated that nonenveloped viruses can employ additional escape route as a viral quasispecies population, via membrane-bound vesicles, as found in several enteroviruses, including hepatitis A virus, hepatitis E virus, bluetongue virus, coxsackievirus, rhinovirus, and poliovirus (Altan-Bonnet and Chen 2015).

Seroepidemiological surveys, conducted so far throughout the world show that seroprevalence of BKPyV/JCPyV, SV40, KIPyV, WUPyV and MCPyV is high in those populations (Brown et al. 1975; Stolt et al. 2003; Kean et al. 2009). Antibodies to both BKPyV and JCPyV are present in $70-80 \%$ of the adult population. The viruses appear to be ubiquitous, with almost no region of the world being free of anti-PyV antibodies, except in some remote populations (Brown et al. 1975). Primary infections with BKPyV and JCPyV viruses probably occur in childhood and are presumed to be subclinical (Padgett and Walker 1973; Shah et al. 1973). The viruses presumably harbor peripheral blood lymphocytes or can remain latent in the kidney [Salzman (ed.), 1986; Dorries et al. 1994; Greenlee, 1997]. It has been hypothesized that the human PyVs probably persist indefinitely in the kidney and are reactivated and excreted in 
the urine during immunological impairment (Heritage et al. 1981; Arthur et al. 1986). Immunosuppression or other viral infections may also lead to reactivation of PyVs. This model of infection may be true to all human PyVs including WUPyV and KIPyV (Heritage et al. 1981; Arthur et al. 1986; Gaynor et al. 2007; Allander et al. 2007).

There has been a resurgence of interest in the study of occurrence, genotype and pathogenic associations of human PyVs in the recent years, especially after the discovery of MCPyV which has been implicated strongly in the etiology of MCC. With the growing incidences of acquired and induced immunosuppression, a thorough knowledge in PyV-host interactions may be beneficial in their control from the standpoint of developing antiviral formulations. This review encompasses the current knowledge on interactions of PyV proteins with cellular components during virion entry, infection, replication and egress from the infected cells.

\section{Human Polyomavirus and Disease}

The name 'polyoma' is derived from the Greek terms: poly, meaning many, and oma, meaning tumors and were named so because they were shown to cause a wide variety of tumors when artificially inoculated into neonatal rodents (Primrose and Dimmock 1980). Polyomaviruse particles are of about $500 \AA$ diameter, having a sedimentation coefficient of $240 \mathrm{~S}$. The capsid is made up of 360 copies of the major capsid protein VP1 arranged in 72 pentamers that are connected to the internal viral protein VP2 or VP3, the minor constituents of the viral capsid. The genome is divided into two major regions, an 'early' region, expressed prior to the initiation of viral DNA replication, and encodes three to four viral tumor antigens (T/t/mT- antigens; LTAg/STAg/MTAg); and a 'late' region that typically encodes three viral capsid proteins (VP1, 
VP2 and VP3). However, MCPyV virions, having native viral regulatory sequences, do not seem to express detectable amounts of VP3 capsid protein in cell culture system (Schowalter and Buck 2013). A small nonstructural protein, agnoprotein or Leader Protein 1 (LP1), is also encoded from the late leader region in few PyVs (SV40, BKPyV and JCPyV), however, other characterized human PyVs do not seem to express this protein. Agnoprotein seems to have roles in viral gene expressions, replication and virus release (Gerits and Moens, 2012). SV40 VP4, a newly identified late gene product, expressed very late during cell lysis, has been found to interact with experimental biological membranes and facilitate their disruption (Daniels et al. 2007; Raghava et al. 2011). A non-coding regulatory region or Non-Coding Control Region (NCCR), comprising of the viral origin of replication, is present between the 'early' and 'late' coding regions. The NCCR is the most variable genomic region that contains regulatory elements and usually undergoes sequence rearrangements during reactivation, thus largely influencing the outcome of the infection. Diverse deletion/duplications within the NCCRs from immunocompromized patients have been shown to augment early gene expression and rate of replication in BKPyV and JCPyV (Gosert et al. 2008; Gosert et al. 2010).

The major capsid protein VP1 $(\sim 45 \mathrm{kDa})$ is required in the capsid assembly and the minor capsid proteins - VP2 $(\sim 38 \mathrm{kDa})$ and VP3 $(\sim 27 \mathrm{kDa})$ help in the uncoating process when the viruses penetrate host cells. Polyomavirus infection in permissive cells is initiated by the binding of the virion to a receptor on the outer cell membrane. The tumor antigens ( $\mathrm{T} / \mathrm{t}$-antigens) are known to alter the cellular control systems and have a key role in replication, transcription of late viral genes and assembly of virions (Brodsky and Pipas 1998).

BKPyV: The reactivation of BKPyV in immunocompromised host has been associated with haemorrhagic cystitis, BKV-nephropathy, and ureteral stenosis. BKPyV associated post- 
transplant nephropathy is a prominent cause of renal transplant dysfunction and has become a clinical problem in allograft recipients (Hirsch 2002; Trofe et al. 2002). The typical renal histological finding of BKPyV-associated nephritis refers to scattered interstitial inflammatory cell infiltration, lysis, atrophy, necrosis of the tubular epithelium, and fibrosis of the interstitium (Drachenberg et al. 2005). Human renal proximal epithelial cells (HRPTEC) are considered to be one of the principal natural targets of BKPyV. Persistence of PyVs in patients with renal allografts may be the important cause of progressive graft dysfunction and graft loss. BKPyV persists in the urinary tract of the individual and are shed in the urine asymptomatically. BKPyV exists in four genotypes (I - IV) and subtypes and are distinguishable by neutralization serology (Pastrana et al. 2013). Subtype Ia is thought to be the most prevalent subtype and is prevalent worldwide and subtype IV is less common and its prevalence appears to vary in different world regions (Jin et al. 1993; Jin 1993; Takasaka et al. 2004).

JCPyV: JCPyV was isolated from the brain tissue of a 38 year-old man whose initials were 'JC' (Padgett et al. 1971). JCPyV, a human neurotropic polyomavirus, is associated with neurological diseases such as PML (Progressive Multifocal Leucoencephalopathy). PML, a rare fatal demylenating disease of the central nervous system, occurs in individuals with immunosuppression involving both humoral and T-cell mediated immune response and is mainly observed in 3\%-5\% HIV-infected individuals (Major 2010). It has also been observed as a late complication in patients with chronic lymphocytic leukemia, Hodgin's disease, lymphosarcoma, sarcoidosis (Gardner et al. 1984; Greenlee 1997). The main symptoms of the disease include cognitive impairment, visual deficit and motor dysfunction, although it may vary based on the location and size of the lesions. The role of JCPyV in malignant transformation is controversial. JCPyV virus was thought to exist in five to ten or more genotypes and Type 6 from West Africa 
represents the ancestral JCPyV genotype (Pavesi 2003). Several Asian subtypes have been identified and the Indian subtype have been designated as Type 2D (Cui et al. 2004). However, recent viral metagenomic analyses by Buck and others suggest that distantly related PyVs may recombine to produce new chimeric lineages and that PyVs may have slowly co-evolved with individual host animal lineages through an established mechanism known as intra-host divergence (Buck et al. 2016). This led the group to propound a modified classification scheme of the Polyomaviruses that account for these intra-host diversifications.

MCPyV: MC polyomavirus (MCPyV) was detected in Merkel Cell Carcinoma (MCC) (Feng et al. 2008) and has been found to be present in $80-85 \%$ of MCC tumor specimen (Dalianis and Hirsch 2013, and references therein). MCPyV has been associated with cellular transformation in highly aggressive primary cutaneous neuroendocrine skin neoplasm termed as MCCand is considered the only human polyomavirus to date to cause tumors in its natural host (Arora et al. 2012; Spurgeon and Lambert 2013). During detection of the virus the LTAg was found to be truncated before the helicase domain in $80 \%$ of the cases (Duncavage et al. 2009), however maintaining pRb-binding ability, and the VP1 region to be deleted (Sharp et al. 2009). MCPyV DNA has been detected mostly in non-melanoma skin cancers such as in squamous cell carcinoma, basal cell carcinoma and Bowens disease in immunosuppressed individuals (Kassem et al. 2009). Apart from detection in MCC and other disease, MCPyV has been detected in upper (Bialasiewicz et al., 2009; Goh et al., 2009) and lower respiratory tract infections (Babakir-Mina et al. 2010).

KIPyV and WUPyV: Both KIPyV and WUPyV were discovered in the year 2007 in bronchoalveolar lavage and nasopharyngeal aspirates (Allander et al. 2007; Gaynor et al. 2007). KIPyV and WUPyV have been detected worldwide in respiratory specimens and clinical samples 
(Babakir-Mina et al. 2008; Babakir-Mina et al. 2009; Kiasari et al. 2008; Bialasiewicz et al. 2008; Foulongne et al. 2008; Payungporn et al. 2008; Abed et al. 2007; Han et al. 2007; Le et al. 2007) suggesting a widespread infection but their involvement in human disease or tumor development is not clear (Giraud et al. 2008; Giraud et al. 2009). Reactivation and excretion of $\mathrm{KIPyV} / \mathrm{WUPyV}$ have also been reported in the gastrointestinal tract of immunosuppressed transplanted patients (Siebrasse et al. 2016) and in HIV-patients (Sharp et al., 2009).

HPyV6 and HPyV7: Human polyomavirus 6 and Human polyomavirus 7 were first found in the year 2010 during a study that involved isolation of full-length wild-type MCV DNA from the skin of healthy volunteers (Schowalter et al. 2010). Both HPyV6 and HPyV7 have been detected in urine, faces and nasopharyngeal swabs in transplant recipients (Siebrasse et al. 2012). Their relationships with a disease in immunosppresion or in malignant transformations have recently been indicated in few studies (Schrama et al. 2014; Ho et al. 2015). A novel HPyV7 strain has recently been associated with HIV/AIDS-associated pruritic rash (Nguyen et al. 2016).

TSPyV: The intracellular presence of virus particles in a patient with trichodysplasia spinulosa was first demonstrated in 1999 (Haycox et al. 1999). Identification of the virus was not achieved until much later in plucked facial spines of a heart transplant patient with trichodysplasia spinulosa (Meijden et al. 2010). Trichodysplasia spinulosa (TS) is a rare skin disease in immunocompromised hosts and is characterised by the development of facial follicular papules and keratotic protrusions (spicules or spines) with alopecia of the eyelashes and brows (Haycox et al. 1999; Heaphy et al. 2004; Osswald et al. 2007; Sadler et al. 2007; Lee et al. 2008; Schwieger-Briel et al. 2010). The presence and high seroprevalence of TSPyV in healthy individuals suggest a subclinical latent infection. The development of tumor with TSPyV remains to be investigated. 
HPyV9: Human polyomavirus 9 was first discovered in the serum of a kidney transplant patient (Scuda et al. 2011) and has not been associated with any disease till date. The phylogenetic analysis of HPyV9 genome showed high similarity with the genome of the African Green Monkey-derived lymphotropic polyomavirus (LPV) than with other PyVs.

MWPyV: MWPyV was isolated from a stool sample of a healthy child from Malawi (Siebrasse et al. 2012). In another study done by Buck et al. a virus was identified in the specimen of a patient with warts with hypoglobulinemia, infections, and myeloathexis syndrome and was named HPyV10 that has $95 \%$ to $99 \%$ similarity with MWPyV, suggesting that they were the same virus (Buck et al. 2012). More recently, a human polyomavirus named MXPyV was detected in stools of children ( $\mathrm{Yu}$ et al. 2012), which was found to be closely related to MWPyV/HPyV10. The association of the virus with infection in the gastrointestinal system or any other disease remains to be investigated.

STLPyV, HPyV12 and NJPyV: STL polyomavirus (STLPyV) was recovered from the fecal microbiota of a child in Malawi. However, its association with diarrhea is not significant. Sequence comparison with other polyomaviruses revealed that the virus shares maximum similarity with the MWPyV (Lim et al. 2013). HPyV12 was detected in the liver as well as colon, rectum, and feces of a single individual but its relation to the disease in human remains to be investigated (Korup et al. 2013). The most recently discovered species, NJ polyomavirus (NJPyV), was isolated from the muscle biopsy of a 33-year-old pancreatic transplant recipient (Mishra et al. 2014). The name New Jersey polyomavirus was after the place from where the patient belonged. 


\section{Viral Entry}

The mechanism of virus entry in non-enveloped viruses can involve various mechanisms such as disruption of endosome at low internal $\mathrm{pH}$ in Adenovirus, pore formation at the plasma membrane or endosomes in Poliovirus or entry via caveolae in SV40 (Marsh and Helenius 2006; Mudhakir and Harashima 2009).

Receptors/Coreceptors: A number of cell surface receptors have been identified of which, few act as single molecular species and few as multiple-receptor set for viruses. Some other viruses depend on a more complex receptor which involves interaction with at least two distinct plasma membrane components. Virus-host cell receptor interactions are specific and use distinct receptors and entry mechanisms to infect cells (Table 1). Glycoproteins are proteins containing oligosaccharide chains covalently attached to polypeptide side-chains and glycolipids are lipids attached to the carbohydrate by a glycosidic bond. Gangliosides (GD1a, GD1b, GT1b, and GM1) are glycolipids i.e. glycosphingolipids with one or more sialic acids (e.g. n-acetylneuraminic acid, NANA) linked differentially to the sugar chain. More than 60 gangliosides are known that differ from each other mainly by the position and number of NANA residues. Sialic acid is N- or O-substituted derivative of neuraminic acid, a monosaccharide with a 9-carbon backbone and is found mostly in glycoproteins and gangliosides. Glycosaminoglycans (GAGs) or mucopolysaccharides are long unbranched polysaccharides that consist of a repeating disaccharide unit consisting of an amino sugar along with uronic sugar or galactose except for keratan.

High resolution crystal structures of truncated murine PyV (mPyV) VP1 protein, complexed with branched disialylated hexasaccharide receptor fragments, were instrumental in 
revealing the roles played by VP1 pentamers in contacting cellular sugar moieties. Each subunit of the VP1 pentamer has two antiparallel $\beta$-sheets with jelly-roll topology, and some of the loops that connect the $\beta$-strands are extensive, containing additional secondary structure elements (a small three-stranded anti-parallel $\beta$-sheet, one $\alpha$-helix, and four $3_{10}$-helices) (Stehle and Harrison 1996; Stehle and Harrison 1997). These studies showed that at least three surface grooves (pockets 1, 2 and 3) of mPyV VP1 are important in recognizing $\alpha 2,3-$ linked $\alpha-5-\mathrm{N}$ acetylneuraminic acid (sialic acid, SA or NANA) on the surface of susceptible cells. In addition to the usual $\alpha 2,3$-linked sialic acid, some mPyV strains also bind to branched oligosaccharides that carry a second 22,6 -linked sialic acid. Binding of low tumorigenicity strains to the branchedchain receptors depends on the presence of glycine at position 91 on the outer surface of VP1 (Fried et al. 1981; Cahan et al. 1983; Stehle et al. 1994; Stehle and Harrison 1997). PyV VP1 residues Tyr-72, Arg-77, Gly-78, His-298, and Asn-93 were identified as essential components of pockets 1 and 2. Single mutations in these residues resulted in the complete loss of infectivity (Stehle et al. 1994; Stehle and Harrison 1997). Based on binding and flotation assays Tsai et al (2003) later demonstrated that specific gangliosides, GD1a and GT1b for mPyV and GM1 for SV40, can serve as plasma membrane receptors. Their model, based on crystal structure of VP1oligosaccharide complex, indicated that the sialic acid- $\alpha 2,3-\mathrm{Gal}$ moiety on the left branch of GD1a can interact with VP1, as proposed by others (Stehle et al. 1994; Stehle and Harrison 1996; Stehle and Harrison 1997) (Figure 1). GT1b ganglioside, which has an additional attached sialic acid (residue 4R) can also bind VP1, and therefore, suggests binding of different mPyV strains equally to both GD1a and GT1b (Tsai et al. 2003). Structurally and biologically similar SV40 has also been shown to interact with GM1 gangliosides in flotation and immunoblotting assays (Tsai et al. 2003). 
To investigate the linkage of sialic acid in BKPyV infection, Vero cells were treated with Vibrio cholerae neuminidase (NA) or Streptococcus pneumonia sialidase S (SAS) and then challenged with the virus (Dugan et al. 2005). Both NA and SAS inhibited infections, that suggested a role for $\alpha 2,3$-linked sialic acid in BKPyV infections. The investigators also examined the role of specific linkages of sialic acids in infection and to determine whether glycoproteins or gangliosides were involved in infection through complete removal of sialic acid from Vero cells. The results suggested that $\alpha 2,3$-linked sialic acid on an N-linked glycoprotein is sufficient to mediate infection (Dugan et al. 2005). Low and coworkers used gangliosidecontaining liposomes in a binding assay with purified BKPyV and further proved that terminal a2-8-linked disialic acid motif present in the GD1b and GT1b gangliosides plays an important role in these interactions (Low et al. 2006). Studies based on VLP-based neutralizing assays indicated that VP1 capsid proteins of each of the major BKPyV genotypes can reciprocally escape from neutralization by antibodies raised against the other types. These serotype-defining differences between the genotypes can be related to a few key amino acid differences within the VP1-BC2 surface loop (Pastrana et al. 2013). Based on cell-based transduction assays, this study also indicated that different BKPyV genotypes and sub-types may have altered attachment requirements and virulence potential in vivo, reflecting the changes in amino acids within their VP1 capsomere knob (Pastrana et al. 2013). Komagome and co-workers found through screening that, the virus-like particles (VLP) containing the JCPyV major viral capsid protein VP1 had the highest affinity for neoglycoproteins containing the terminal $\alpha 2-6$-linked sialic acid (Komagome et al. 2002). While it was clearly established that PyV infections depend on an interaction between VP1 and sialic acids, a glycan-array screening and infectivity assay further established that JCPyV interacts with a linear sialyated penta-saccharide with the sequence NeuNAc- $\alpha 2,6$ - 
Gal- $\beta 1,4-G l c N A c-\beta 1,3-G a l-\beta 1,4 G l c$ (Lactoseries tetrasaccharide c or LSTc) on host glycoproteins and glycolipids (Neu et al. 2010). Conflicting results are now available with regard to the cellular entry of JCPyV. One set of experiments suggests that JCPyV internalization and cellular entry depends on the expression of serotonin receptor 5-hydroxytryptamine (5-HT) receptor 5-HT ${ }_{2 \mathrm{~A}} \mathrm{R}$ in the susceptible cells after attaching to sialylated sugars (Elphick et al. 2004; Assetta et al. 2013). While in vitro studies of Chapagain and co-workers suggested that JCPyV infection in the human brain microvascular endothelial cells is independent of $5 \mathrm{HT}_{2 \mathrm{~A}} \mathrm{R}$ receptor (Chapagain et al. 2007). A subsequent study has shown that there could be a sialylated glycanindependent infectious entry pathway for both JC and BKPyV, as found in heparin-like glycandependent MCPyV infection (Schowalter et al. 2011). The study reports complete inhibition of cellular entry of PML-mutant JCPyVs and a sialic acid non-binding mutant BKPyV, when blocked by heparin or a heparan sulfate-blocking antibody (C. B. Buck, personal communication; manuscript in preparation) (Figure 2).

High resolution crystal structures of HPyV6 and HPyV7 VP1 revealed the presence of elongated loops that cover the bulk of the outer virion surfaces and obstruct a groove that binds sialylated glycan receptors as in other PyVs (Stroh et al. 2014). This study could not detect interactions of VP1 with $\alpha 2,3$ - and $\alpha 2,6$-linked sialic acids by nuclear magnetic resonance spectroscopy, hence HPyV6 and HPyV7 probably engage non-sialylated cellular receptors for host cell recognitions. Liposome floatation assay of Erickson et al. (2009) proved that the sialic acids on both the arms of GT1b are necessary for binding MCPyV VP1, but GD1a, having $\alpha 2,3$ linked monosialic acid modification on the right arm, and GD1b, having no sialic acid on the left arm, do not bind to MCPyV VP1. However, sialylated glycans are not required for the initial interaction of MCPyV with cultured human cell line but may be required as co-receptors in the 
entry process. Glycosaminoglycans (GAGs), such as heparan sulfate and chondroitin sulfate, serve as primary receptors during the entry process (Schowalter et al. 2011; Schowalter et al. 2012).

Systems virology has been instrumental in the global understanding of hitherto unknown virus-host interactions and especially of the dynamic nature of host responses against viruses (Bhattacharjee 2015). Therefore, this approach can discover new mutations in PyV VP1 genes, their implications in tissue tropism, potential for cross-species infectivity, and also in the development of host-based anti-viral drugs (Kilcher and Mercer, 2014). Interestingly, in a recent study, an intra-patient evolution of BKPyV has been shown to produce neutralization-escape VP1 variants that may have altered tissue tropism through binding to a different spectrum of cellsurface sialylated glycan receptors compared to the wild type viruses (C. B. Buck, personal communication; manuscript in preparation).

Receptor Mediated Endocytosis: All PyVs, except JCPyV, generally enter the host cells through structures called 'caveolae' present in the plasma membrane of the host (Anderson et al. 1996; Richterova et al. 2001; Pelkmans and Helenius 2003; Damm et al. 2005; Dugan et al. 2006; Parton and Simons 2007). However, SV40 can enter and infect cells by a clathrin-, caveolae- and dynamin II-independent pathways that deliver the virus via non-endosomal, cytosolic organelles to the ER. This work was based on detection of LTAg in caveolin-1 deficient post-infected mouse embryonic fibroblast and human hepatoma cell line (Damm et al. 2005).

Growing body of evidences indicates that viruses, including nonenveloped viruses, can use specific membranes microdomains or 'membrane rafts' to penetrate the host cell. Caveolae 
are lipid-raft rich, flask-shaped, 50-100 nm invaginations present in the plasma membranes that are stabilized by VIP-21 or caveolins (e.g., caveolin-1 or cav-1), containing mostly cholesterol and sphingolipid (Rothberg et al. 1992). Caveolin-2 is often associated with caveolin-1 in the same cell or tissue types, whereas expression of caveolin-3 is found in skeletal and cardiac muscles. Caveolae are present at high concentrations on several cell types such as adipocytes, muscle cells, endothelial cells, but few or none in hepatocytes, neuronal cells, and lymphocytes. Most cell surface caveolae show limited motility and dynamics, anchored by actin cytoskeleton that play a key role in controlling their activity and keeping them in place (Thomsen et al. 2002).

SV40 first binds to the major histocompatibility complex class I (MHC-I) antigens on the cell surface and is then trapped in the caveolae, which pinches off as vesicle that contains caveolin-1 (Breau et al. 1992; Pelkmans et al. 2001). Subsequent internalization of the virus requires activation of tyrosine kinases and dynamin II (GTPase) driven GTP hydrolysis, that result in a signaling cascade leading to slow but efficient internalization (Oh et al. 1998; Pelkmans et al. 2002; Parton and Richards 2003). After internalization, some of the caveolar ligands are then sorted to endosomes and the Golgi complex or transported to cav-1-positive, pH-neutral caveosomes (Pelkmans et al. 2001; Parton and Richards 2003). From the caveosomes, SV40 is transported by a microtubule-mediated process to the ER (Pelkmans et al. 2001), and then is released into the cytosol. From the cytosol, the virus particles enter the nucleus through nuclear pore complexes (Kasamatsu and Nakanishi 1998).

Early studies indicated that the binding of poliovirus and papillomaviruses to the cell receptors promotes conformational changes in the major capsid proteins VP1, which are then transmitted to the other capsid proteins (Magnuson et al. 2005; Schelhaas et al. 2007). This conformational change results in the exposure of hydrophobic sequences at the viral capsid 
surface that may participate in membrane penetration. These conformational changes in the viral capsid proteins could be detected by changes in their sensitivity to proteases or in the antigenic properties of the viral proteins (Fricks and Hogles 1990; Selinka et al. 2003). The recognition of sialic acid moieties on host cell membrane proteins induces conformational changes in both major and minor capsid proteins, as evidenced by resistance to protease (e.g., trypsin) digestion by the VP1-SA complexes, which is probably required for binding to entry receptors and internalization, thus is crucial for productive infection in mPyV (Cavaldesi et al. 2004).

Kinetics and mechanisms of BKPyV entry have been studied in monkey kidney cell line Vero to investigate the roles of clathrin-dependent or caveola-dependent endocytosis (Eash et al. 2004; Eash and Atwood 2005). Several important findings emanated from these studies: virus internalization is slow and occurs between 2 and 4 hours post-infection, is independent of clathrin-coated-pit assembly, dependent on an intact caveolin-1 scaffolding domain and microtubule network, sensitive to tyrosine kinase inhibition, and requires membrane cholesterol. Similar results were observed in the study of BKPyV entry into human renal proximal tubular epithelial cells HRPTEC (Moriyama et al. 2007). The JCPyV virus enters into the target cells via clathrin-mediated endocytosis, dependent on actin polymerizationa and proper assembly of clathrin-coated pits, and is comparatively faster than the entry kinetics of SV40 (Pho et al. 2000). After entry into the cells, the virus localizes to the early and late endosomes and is hydrolyzed within the lysosome and therefore, unlike SV40, a low pH environment within the lysosome is critical for the productive JCPyV infection (Ashok and Atwood 2003). Cytoplasmic transport of JCPyV in glial cells depends on microtubule and intermediate filament, as evidenced by the sensitivity of productive infection to cytochalasin D, nocodazole, and acrylamide (Ashok and Atwood 2003). Their data suggested that microtubules may be involved either directly with the 
viral proteins or through a dynactin-independent dynein family member, or microtubules may be required for transport of intermediate filament-associated proteins and hence proper assembly of intermediate filaments facilitating JCPyV transport to the nucleus (Ashok and Atwood 2003). While it was known that the engagement of SV40 to cell surface receptors can induce tyrosine kinase-mediated phosphorylation of caveolin-1 (Dangoria et al. 1996), JCPyV binding to human glial cells induces intracellular signal that triggers downstream phosphorylation or activation of the MAPKs ERK1 and ERK2, and the viral entry is dependent on involvement of the endocytic protein eps15 (Querbes et al. 2004).

$\mathrm{MCPyV}$ is a member of a divergent clade of polyomaviruses that lack the conserved VP3 N-terminal motif. Schowalter and Buck (2013) also showed that VP3 is neither detectable in $\mathrm{MCPyV}$-infected cells nor found in native MCPyV virions. Experimental mutation of possible alternative VP3-initiating methionine codons did not significantly affect MCPyV infectivity in culture and VP2 knockout resulted in a 100-fold decrease in native MCPyV infectivity. Their pseudovirus-based experiments confirmed that VP2 plays an essential role in infection of some cell but not in all. Their work also showed that myristoylation of N-terminus of VP2 was important for its function.

ER mediated viral trafficking: Complex membranous network within the host cell such as plasma, endolysosomal, and endoplasmic reticulum (ER) membranes, owing to its specialized ER-to-cytosol retro-translocation machinery, have an important role in the initiation and progression of viral infections (Inoue and Tsai, 2013). Polyomaviruses are the only viruses known to penetrate the ER membrane during entry into the host (Tsai et al. 2003; Inoue and Tsai, 2013). Earlier electron microscopic studies revealed that the virus enters into host cells as small 
vesicles and are then targeted to the ER (Mattern et al. 1966; Mackay and Consigli 1976; Kartenbeck et al. 1989). Upon arrival on to ER, SV40 is released into the ER lumen from GM1, presumably through a release process involving ER-resident proteins (Inoue and Tsai 2011).

The ER-localized SV40 is large and intact, contains the minor capsid proteins VP2, VP3, and the genome. The intact viral particle then penetrates the ER membrane to reach the cytosol where it disassembles (Inoue and Tsai 2011). During penetration of the ER, the virus first undergoes host-triggered conformational changes which then cross the ER membrane, and then finally is released into the cytosol (Inoue and Tsai 2013). Conformational changes in PyV capsid, the disassembly process and transport of its genetic material from ER to the cytosol require the participation of several putative ER-resident proteins. ER-resident redox-active protein disulfide isomerase family members (PDI, ERp57, and ERp72) can isomerize or reduce the virus disulfide bonds and can play an important role in destabilizing PyV-VP1 disulphide bond network (Inoue and Tsai 2013). However, the precise combination of PDI members engaging a specific PyV family member may differ because of subtle differences in the viral disulfide bond arrangements. In some PyVs, a dimeric redox-inactive PDI protein (ERp29) untangles the VP1 carboxyterminal arms exposing hydrophobic VP2 and VP3 to generate a hydrophobic viral particle (Magnuson et al. 2005; Rainey-Barger et al. 2007). The hydrophobic virus is probably maintained in a soluble state by binding to the $\mathrm{Hsp} 70$ chaperone $\mathrm{BiP}$ in a reaction regulated by the J-domain containing co-chaperone ERdj3 (Goodwin et al. 2011).

In the second step, the hydrophobic virus integrates into the ER membrane to initiate membrane penetration, where ER-associated degradation (ERAD) membrane components (Derlin-1, Derlin-2, Sel1L, RMA1, BAP29/BAP31) have been proposed to facilitate PyV's exit, at least indirectly, to the cytosol (Inoue and Tsai 2013 and references therein). Although not 
well-understood, the release of virions into the cytosol may depend on the ER membrane $\mathrm{J}$ proteins (DNAJ B12, B14, and C18) that stimulate the binding between the virus and cytosolic Hsp70 (Inoue and Tsai 2013). The SV40 capsid proteins VP2/VP3 have been shown to play an important role in the ER escape (putatively through viroporin) and are regulated by their interaction with VP1 major capsid protein (Daniels et al. 2006a; Daniels et al. 2006b). ERp29, structurally related to PDI protein (Mkrtchian et al. 1998), acts as a factor in inducing a conformational change in PyV particles by exposing the C-terminus of VP1 protein without the complete disintegration of the virion structure (Magnuson et al. 2005). Portions of VP2 and VP3 are also exposed that mediate the binding to the ER membrane, although only VP2 can perforate the experimental model membranes (Rainey-Barger et al. 2007).

The ERAD pathway during BKPyV intracellular trafficking has been studied in renal proximal tubule epithelial (RPTE) cells using proteasome and ERAD inhibitors (Jiang et al. 2009; Bennett et al. 2013). Transfection of dominant-negative ER-transmembrane proteins Derlin-1 and Derlin-2 in RPTE cells and GST pull-down assays revealed the involvement of Derlin-1, but not Derlin-2, in BKPyV escape from ER to the cytosol (Jiang et al. 2009; Bennett et al. 2013). Proteasome function was also indicated in successful BKPyV trafficking, like SV40, in proteasome-inhibition-assays (Bennett et al. 2013).

\section{Nuclear Entry and Replication}

Nuclear entry: Nuclear transport of molecules less than $9 \mathrm{~nm}$ in diameter or proteins smaller than $40 \mathrm{kDa}$ pass through the aqueous channels of nuclear pore complex (NPC) by passive diffusion but transport of larger molecules $(>45 \mathrm{kDa})$ is mediated by facilitated nuclear transport 
that requires signals on both, the molecule to be transported and on the cytoplasmic receptors (Pante and Kann 2002 and references therein; Wente and Rout 2010).

Nucleocytoplasmic transport of cargo $>45 \mathrm{kDa}$ depends on transport factors belonging to the family of karyopherin $\beta$ proteins (e.g, importin $\beta /$ importin $\alpha$ or $\operatorname{IMP} \beta / \operatorname{IMP} \alpha$ ). The $\beta$ karyopherins that mediate nuclear import are generally known as importins (IMPs), whereas those mediating nuclear export are known as exportins (EXPs). The IMP $\alpha$ s are adaptors that function as heterodimers with IMP $\beta 1$ in nuclear import, while IMP $\beta$ s can mediate transport in either direction through the NPC (Fulcher and Jans 2011). Importins associate with their macromolecular cargo in the cytoplasm, either directly or indirectly via adaptor proteins. They dock to components of the nucleoporins, translocate to the opposite side of the nuclear envelope to release their cargo. The cargo release is achieved by association of the importins with the GTPase Ran in the GTP-bound form (RanGTP). In nuclear export, cargo recognition occurs in the nucleus in the presence of RanGTP and the complex dissociates in the cytoplasm upon GTP hydrolysis. A variety of strategies has been employed by viruses for the transport of their genomic cargo that includes disassembly at the NPC, disruption of the NE or may involve both of them (Fay and Pante, 2015). The nuclear entry/exit of cargo protein involves NPC on the nuclear membrane, recognition of nuclear localization sequences (NLSs) on the proteins to be imported by specific IMPs/EXPs (Lange et al. 2010; Wente and Rout 2010; Marfori et al. 2011; Fulcher and Jans 2011).

SV40 must expose NLSs that are internal in the virion architecture in order to enter the nucleus via interaction with the host's nuclear import machinery. SV40 may escape from the ER to the cytoplasm and then enter the nucleus through the NPC, or it may enter the nucleus directly from the ER by penetrating the inner nuclear membrane (INM); the available data favors the 
former possibility (Cohen et al. 2011). SV40 particles undergo a partial disassembly in the ER which exposes internal capsid proteins VP2 and VP3. The partially disassembled SV40 particles retain some of the SV40 capsid proteins (VP1, VP2, and VP3) in addition to the viral genome (Norkin et al. 2002). The best characterized nucleotransport signal is the classical NLS (cNLS) for nuclear protein import, which consists of either one (monopartite) or two (bipartite) stretches of basic amino acids. Monopartite cNLSs are exemplified by the SV40 LTAg-NLS $\left({ }^{126} \mathrm{PKKKRRV}^{132}\right)$ (reviewed in Lange et al. 2007). Accessibility and enhancement of nuclear transport depend on phosphorylation-mediated modulation of NLS/NES of the protein cargo. In SV40 LTAg, protein kinase CK2 phosphorylation increases the affinity of recognition of the NLS by IMP $\alpha / \beta 1$, thereby accelerating the nuclear import rate, which can be further enhanced by phosphorylation by double-stranded DNA-dependent protein kinase (dsDNA-PK) at specific sites (Fulcher and Jans 2011). The SV40 virion may enter the nucleus through the NPC through the interactions between NLSs at the common C-terminal basic amino acids of VP2 and VP3 (VP1/VP2-NLS) and the canonical nuclear import machinery (Nakanishi et al. 2002; Nakanishi et al. 2007). Anti-IMP $\alpha / \mathrm{IMP} \beta$ antibody-based co-immunoprecipitation assays with SV40 DNA post infection in permissive cells indicated that minor capsid proteins must associate with virion DNA for nuclear entry (Nakanishi et al. 2002; Nakanishi et al. 2007). Only a small fraction of virions that expose an NLS deliver their genomes into the nucleus, however, a complete dissociation of the virion within the cell cytoplasm prevented the nuclear entry of the viral DNA (Nakanishi et al. 2002; Nakanishi et al. 2007). Kuksin and Norkin (2012) reported that VP2/VP3-NLS may function only in targeting SV40 disassembly intermediates to the nucleus but SV40 genomes dissociate from VP2/3 before or at the point of nuclear entry and thus enter the nucleus devoid of these viral proteins. However, contrasting views on nuclear entry of SV40 
have been provided by a study which indicated that viral infection leads to a breakdown of the nuclear lamina and disruption of the nuclear envelope, allowing the virus to pass directly from the ER lumen to the nucleus (Butin-Israeli et al. 2011).

Since BKPyV-VP2/VP3 share homology with that of SV40 at the basic C-terminal amino acids important for nuclear localization, elegant site-directed BKPyV VP2/VP3-mutation and drug-based inhibition of IMP $\beta$ in RPTE cells have been designed to ascertain the commonality of nuclear entry mechanism (Bennett et al. 2015). This study could show that specific lysines in VP2/VP3 are important for localization of BKPyV to the nucleus and that VP2K319T and VP3K200T mutants were defective in nuclear localization. The importance of the major capsid protein VP1 was reiterated, as in SV40, by showing that expression of this protein in transfected cells enabled nuclear transportation of mutated minor proteins (VP2K319T and VP3K200T). It was also shown in ivermectin-based inhibition assay that the inhibition of IMP $\alpha / \beta$ largely affected early gene expression of BKPyV in RPTE cells. In an earlier study by Qu et al. (2004), nuclear entry mechanism in JCPyV was studied that used FITC-labeled JCV-VLP in infection of HeLa (non-permissive) and SVG (permissive) cells. Post-infection fluorescence study showed that the nuclear entry of NLS-deleted-VLPs was markedly inhibited in HeLa/SVG cells, highlighting the importance of VP1-NLS in the nuclear translocation of VLPs. This study also indicated the importance of both IMP $\alpha$ and $\beta$ in the nuclear entry by JCPyV-VLPs (Figure 3). Nuclear sequestration of human endogenous hVam6p (involved in cytoplasmic lysosomal trafficking) by MCPyV-LTAg has been reported which may help in MCPyV replication and egress (Liu et al. 2011). 
DNA Replication: The replication of PyV minichromosomes has been historically used as a model system to study the mechanisms of cellular DNA replication (Kelly et al. 1988; Challberg and Kelly 1989; Stillman 1989; Hurwitz et al. 1990). There are controversial views with regard to the resemblance of in vitro replication of PyV and the host DNA replication (Fanning et al. 2009). Recent findings indicate that PyV minichromosomes undergo multiple rounds of replication and there is a dispensability of DNA polymerase $\varepsilon$ (epsilon) (Fanning et al. 2009). Additionally, it was found that at least SV40 and mPyV induce an ATM-mediated DNA damage response in infected cells, which might in the contrary arrest normal cell cycle. The present state of knowledge indicates that simian SV40 and mPyV manipulate host DNA damage signaling and repair pathways, in a largely unknown manner, to control viral minichromosome replication (Fanning et al. 2009). In the MCPyV infected cells, components of the ATM- and ATR-mediated DNA damage response (DDR) pathways were found to accumulate in the MCPyV LTAgpositive nuclear foci, suggesting an important role of DDR in viral DNA replication (Tsang et al. 2014).

The in vitro study of SV40 replication has been instrumental in establishing fundamental processes of initiation of eukaryotic DNA replication (Bullock 1997). The replication of SV40 or mPyV DNA requires the viral origin of DNA replication and only one virus-encoded protein, the large T-antigen (LTAg) to replicate the viral mini chromosome. The other necessary 40 proteins, a set of ten human cellular proteins, are supplied by the host cells (Waga and Stillman 1994; Bruckner et al. 1995; Bullock 1997). In JCPyV, Hsp70 interacts with VP2/VP3 and LTAg; and accumulates heavily in the nucleus of the infected cells. An association between the VP2/VP3 and LTAg through their DNA binding domains was also observed, that enhances LT-Ag DNA binding to Ori resulting in the induction of viral DNA replication (Saribas et al. 2014). 
The SV40 origin of replication is a 64 base pair segment of the viral genome (extends between nucleotides 5211 and 31) which contains all the sequence elements required for in vivo and in vitro DNA replication (Deb et al. 1986; Deb et al. 1987; Challberg and Kelly 1989; Bullock 1997). The arrangement of the SV40 and mPyV core origin is very similar to the core origin domains of $\mathrm{BKPyV} / \mathrm{JCPyV}$. The SV40 core origin contains three functional regions: (1) an early palindrome (EP); (2) four GAGGC pentanucleotide sequences, collectively referred to as the pentanucleotide palindrome (PEN) or Binding Site; and (3) 17-bp AT-rich domain. These three domains coordinate the binding, melting, and unwinding activities of LTAg (Borowiec et al. 1990; Bullock 1997). The 71 base pair MCPyV replication origin was shown to include a poly(T)-rich tract and 8 variably oriented, GAGGC-like pentanucleotide sequences, of which 4 are required for the interaction of MCPyV-LTAg (Kwun et al. 2009). The entire origin of MCPyV contains 10 potential LTAg binding sequences (PS1 to PS10) and the optimal initiation of replication requires both the viral STAg expression and intact cellular Hsc70 binding to support efficient viral DNA replication (Kwun et al. 2009).

The SV40 LTAg plays a central role in the initiation of viral DNA replication by means of binding to four pentamer repeats $(\mathrm{PEN})$ of core origin. Once bound to the origin, the LTAg assembles into a head-to-head double hexamer in the presence of ATP. Binding of LTAg causes a significant change in the local DNA structure at the viral replication origin (Kelly et al. 1988; Challberg and Kelly 1989; Stillman 1989; Borowiec et al. 1990; Bullock, 1997). Initially, two LTAg DNA-binding domains (OBD; amino acids 131 to -259) bind to each half of the palindromic sites of the origin and then promote assembly of eight additional LTAg monomers with the concomitant binding of ATP/ADP with the LTAg AAA+ (ATP associated/ATPbinding) domain. Then the duplex DNA at the origin melts through its interaction with $\beta$-hairpin motifs of 
the AAA+ domain of LTAg (Gai et al. 2004; Reese et al. 2006). The remaining four OBDs of the LTAg hexamer interact with the already formed two OBD-PEN complex to form an open spiral and ultimately each hexamer surrounds one strand and displaces the other strand of the origin DNA leading to helicase structure (Reese et al. 2006; Fanning et al. 2009). The role of J domain of viral LTAg, either in a directly or indirectly, seems to be a requisite in viral DNA replication, at least in vivo (Bullock 1997; Sullivan and Pipas 2002). The ATPase activity of LTAg is functionally related to its helicase activity and both the activities are present in the same molecule (Kelly et al. 1988). However, LTAg-mediated unwinding reaction requires the presence of additional cellular proteins, such as single strand DNA binding protein or replication protein A (RPA) and Topoisomerase I and II (Jiang et al. 2006).

Both LTAg and STAg antigens are required for MCPyV-positive MCC cell survival and proliferation (Houben et al. 2012). In enhancing the LTAg-dependent replication, the MCPyVSTAg targets the cellular SCF (complex of Skp1,Cull and F-Box protein) ubiquitin ligase protein complex, $\mathrm{SCF}^{\mathrm{Fbw} 7}$, where, Fbw7 has been shown to be dysregulated/mutated in several cancers and to be important in diverse signaling pathways regulating cell proliferation and tumor suppression (reviewed in Kwun et al. 2013). MCPyV-STAg enhances genome replication by promoting accumulation of the LTAg through the inhibition of Fbw7 (Kwun et al. 2013). This targeting of $\mathrm{SCF}^{\mathrm{Fbw} 7}$ is mediated through an LT-stabilization domain (LSD) of STAg. Mutation in STAg-LSD abolishes stabilization of LTAg, eliminates cell transformation, inhibits viral replication and induction of several cellular oncoproteins, including c-Myc and cyclin E.

In the next step, DNA polymerase $\alpha$-primase (pol-prim) synthesizes RNA primers at the origin of DNA replication (Stillman 1989; Bruckner et al. 1995; Fanning et al. 2009). Experimental evidence indicates that at least two subunits of pol-prim form specific complex 
with helicase domain of each SV40-LTAg hexamer (Challberg and Kelly 1989; Stillman 1989; Huang et al. 1998). The synthesis of nascent RNA primer for DNA synthesis seems to be dependent on the concomitant binding of LTAg to both pol-prim and RPA (Fanning et al. 2009). This event probably leads to compact binding of RPA with the single-stranded DNA which allows pol-prim to gain access to the DNA template for primer synthesis. Similar RPA-ssDNA binding remodeling by LTAg may lead to primer extension by pol-prim and also the switch to DNA polymerase $\delta /$ RFC/PCNA (Fanning et al. 2009).

Agnoprotein enhances the DNA binding activity of LTAg to the viral origin (Ori). Phenylalanine residues are known to have critical roles in protein-protein interaction, protein folding, and stability. Mutation of all the three phenylalanine residues present in the agnoprotein resulted in inefficient replication of mutant virus (Saribas et al. 2012).

\section{Viral Assembly and Egress}

Assembly of virions occurs either in the cytosol or in the nucleus of a host cell that involves polymerization of the capsid protein-like viral minichromosomes (Garber et al. 1980). The release of non-enveloped virus usually occurs through cell lysis. But in some cases, they may escape either by some secretary mechanisms (Altenburg et al. 1980) or use cellular autophagy pathways for exit (Jackson et al. 2005). During maturation, changes in viral chromatin composition can be observed that may include an increase in the level of H3 and H4 histone, acetylation in pre-virion and mature virions, degradation of $\mathrm{H} 1$ histones, and association of nonhistone proteins with mature extracellular virion chromatin complex [Salzman (ed.) 1986].

The SV40 late genes encode viral structural proteins which remain silent during the early phase of infection. Viral structural proteins (VPs) are gradually added to the viral DNA-histone 
complex to form immature virions which subsequently mature to give rise to extracellular mature virions [Fanning and Baumgartner, 1980; Salzman (ed.) 1986]. In vitro studies with expressed VP1 protein of mPyV, JCPyV and BKPyV revealed that it has the capability of self-assembly into virus-like particles (VLPs), and are composed of 72 capsomers that include only pentamers arranged in a $\mathrm{T}=7$ surface lattice (Montross et al. 1991; Chang et al. 1997; Li et al. 2002). These VLPs had the same antigenicity like that of natural viral empty capsids (Li et al. 2002). Heterologous in vivo expression studies showed that the VP1 capsid protein expressed in Saccharomyces cerevisiae and cultured insect cells, retained native antigenic as well as sialic acid-binding capacities (Hale et al. 2002). Disulfide bonds are also found to have an important role in maintaining the integrity of the human polyomavirus VP1 structure by protecting calcium ions from chelation (Chen et al. 2001). DNA binding capacity of JCPyV-VP2 has been studied which showed that the last 13 amino acids, most importantly Lys (332) and Lys (336) within the DNA binding domain of VP2, were essential for this binding (Huang et al. 2001). The host chaperone system, including Hsp70, has an important role in the viral assembly process as it binds to VP1 post-translation. Chromy and co-workers showed that Hsp70 chaperones interact with the C-terminal domain of VP1 to inhibit calcium-mediated capsid assembly in vitro and both prokaryotic and eukaryotic Hsp70 chaperones can assemble VP1 capsomeres in vitro into uniform capsids through an energy-dependent reaction (Chromy et al. 2003). Sucrose gradient sedimentation and cesium chloride gradient ultracentrifugation analyses of the mature virions of agnoprotein-negative JCPyV revealed that they could assemble into irregularly sized virions and that agnoprotein alters the efficiency of formation of VP1-VLPs. Further analyses showed that some fractions of agnoprotein colocalize with VP1 in the nucleus suggesting its role in virion assembly (Suzuki et al. 2012). Some of the viruses assemble at specific intracellular locations, 
often termed 'virus factories' that represent sub-cellular scaffolds, where genomes and capsid proteins are brought together for assembly into virion particles (Erickson et al. 2012). The site for nuclear virus assembly factories is promyelocytic leukemia nuclear bodies (PML-NBs). In $\mathrm{JCPyV}$, the major and minor capsid proteins cooperatively accumulate in the nuclear domain 10 (ND10), also known as PML-NBs, where they assemble in to virion particles (Shishido-Hara et al. 2004).

The process of release of PyV from the host cell has been studied earlier by Clayson et al. (1989), where the workers have observed that the escape mechanism of SV40 does not involve cell lysis and may be released from the apical surfaces of the infected cells. Similarl non-lytic release mechanism has recently been observed in BKPyV (Evans et al. 2015). It was also demonstrated by the group that $\sim 1 \%$ of total infectious virus progeny is released into the media of cultured primary renal epithelial (RPTE) cells by 48 hour post-infection and that this egress route can be inhibited by an anion channel blocker (DIDS) known to affect cellular secretion pathways. However, recent evidences indicate that late agnoprotein (JCPyV) or VP4 (SV40) can act as 'viroporin' and facilitate plasma membrane permeablization/disruption and thus enhancing the viral release (Suzuki et al., 2010; Raghava et al. 2011)

\section{Summary and Concluding Remarks}

In the last few decades, extensive research on the functions of the individual viral proteins in the host cell and that on their interactions with cellular signaling pathways has been instrumental in discovering hitherto unknown virus-host interactions and especially of the dynamic nature of host responses in viral pathogenesis. Initial interaction between a virus and a host cell is mediated by attachment of the viral surface glycoproteins to the host cell surface attachment 
factors, which can be either a glycolipid or a glycoprotein. While mPyV and simian SV40 recognize gangliosides GD1a/GT1b and GM1 respectively, BKPyV utilizes $\alpha 2,3$-linked sialic acid of a glycoprotein and/or $\alpha 2-8$-linked disialic acid motif of the GD1b/GT1b gangliosides (glycolopid) for interating with host cell plasmamembrane. JCPyV recognizes a linear sialylated pentasaccharide (LSTc) on host cell glycoproteins and glycolipids or $\alpha 2-6$-linked sialic acid on glycoprotein for its attachment to host cells. JCPyV has also been shown to bind additionally to a 5-HT2 family of serotonin receptors. However, sialylated glycans (glycolipid and glycoprotein) are not required for initial attachment of MCPyV virions to susceptible cells but may be required as co-receptors in the entry process. Glycosaminoglycans, such as heparan sulfate and chondroitin sulfate, may serve as initial attachment receptors during MCPyV infectious entry to keratinocytes or melanocytes.

Internalization of the virion occurs either by fusion of the envelope and the plasma membrane or via an endocytic pathway which then escapes the endocytic compartment (ER) and enters the cytosol. Caveolae-mediated internalization occurs in all human PyVs except in JCPyV, which employs clathrin-mediated endocytosis. Cellular transport of the virus-cargo to the ER depends on microtubule network. Upon arrival on to ER, viruses are released into the ER lumen, presumably through a release process involving ER-resident proteins. The unique environment within the ER directs specific structural rearrangements in the viral capsid proteins like VP2/VP3, by a process that involves PDI/ERp57 (BKPyV, JCPyV and SV40) or ERp29 $(\mathrm{mPyV})$. The structurally modified virus then engages different retrotranslocons depending on Derlin-1/Sel1L (BKPyV, JCPyV and SV40) or Derlin-2 (mPyV) for their escape to the cytosol. This is followed by further capsid rearrangements and subsequent engagement of nuclear pore complex for delivering the genome to the nucleus. Nucleo-cytoplasmic transport of the viral 
cargo depends on IMP $\beta / \mathrm{IMP} \alpha$. Importins associate with their macromolecular cargo in the cytoplasm via the mediation of adaptor proteins. They dock to components of the nucleoporins, translocate to the opposite side of the nuclear envelope to release their cargo for viral genome replication and packaging. Subsequent to DNA replication and chromatin maturation within the host cell nucleus, virus capsid assembly is initiated. The host chaperone system, including Hsp70, has an important role in the viral assembly process that involves an important role played by agnoprotein, at least in JCPyV. The release of PyVs (e.g., BKPyV) from cells has been reported to be non-lytic in nature and may bud-off from apical surfaces of the infected cells. Viroporin-mediated lytic release of JCPyV is also indicated by few studies.

Polyomavirus VP1 surface-loop variations and key mutations at specific sites appear to be the determinants in intial interactions of this capsid protein in the infectious entry process. Intra-patient mutational variations can also be speculated to be key events in modifying tissuetroism, virulence and subsequent infections. Genetic and protein-level variations existing among the different genus of this virus group, and their interactions with keys proteins of the host cell, can be used in designing a framework for a treatment regime, especially in viruses that have proven pathogenic potential in human. A thorough knowledge regarding virus-host interactions may be instrumental in developing host-centric drug targets, thus avoiding viral resistance.

\section{Acknowledgements}

We thank Dr. C. B. Buck, Laboratory of Cellular Oncology, Center for Cancer Research, National Cancer Institute, Bethesda, Maryland, USA for his critical comments on the draft manuscript. 


\section{References}

Abed, Y., Wang, D., and Boivin, G. 2007. WU polyomavirus in children, Canada. Emerg. Infect. Dis. 13: 1939-1941. doi: 10.3201/eid1312.070909

Allander, T., Andreasson, K., Gupta, S., Bjerkner, A., Bogdanovic, G., Persson, M. A., Dalianis, T., Ramqvist, T., and Andersson, B. 2007. Identification of a third human polyomavirus. J Virol. 81: 4130-4136. doi:10.1128/JVI.00028-07

Altan-Bonnet, N., and Chen, Y-H. 2015. Intercellular transmission of viral populations with vesicles. J Virol. 89: 12242-12244. doi:10.1128/JVI.01452-15.

Altenburg, B. C., Graham, D. Y., and Estes, M. K. 1980. Ultrastructural study of rotavirus replication in cultured cells. J. Gen. Virol. 46: 75-85. doi: 10.1099/0022-1317-46-1-75

Anderson, H. A., Chen, Y., and Norkin, L. C. 1996. Bound simian virus 40 translocates to caveolin-enriched membrane domains, and its entry is inhibited by drugs that selectively disrupt caveolae. Mol. Biol. Cell 7: 1825-1834. PMCID: PMC276029

Arora, R., Chang, Y., and Moore, P. S. 2012. MCV and Merkel cell carcinoma: a molecular success story. CurrOpin.Virol. 2: 489-498. doi: 10.1016/j.coviro.2012.05.007

Arthur R. R., Shah, K. V., Baust, S. J., Santos, G. W., and Saral, R. 1986. Association of BK viruria with haemorrhagic cystitis in recipients of bone marrow transplants. New Eng. J Med. 315: 230-234. doi: 10.1056/NEJM198607243150405

Ashok, A., and Atwood, W. J. 2003. Contrasting roles of endosomal pH and the cytoskeleton in infection of human glial cells by JC virus and simian virus 40. J. Virol. 77: 1347-1356. PMCID: PMC140837

Assetta, B., Maginnis, M. S., Ahufinger, I. G., Haley, S. A., Gee, G. V., Nelson, C. D. S., O’Hara, B. A., Ramdial, S. A., and Atwood, W. J. 2013. 5-HT2 receptors facilitate JC polyomavirus entry. J Virol. 87: 13490-13498. doi: 10.1128/JVI.02252-13 
Babakir-Mina, M., Ciccozzi, M., Dimonte, S., Farchi, F., Valdarchi, C., Rezza, G., Perno, C. F., Ciotti, M. 2008. Identification of the novel KI polyomavirus in the respiratory tract of an Italian patient. J Med. Virol. 80: 2012-2014. doi: 10.1002/jmv.21303

Babakir-Mina, M., Ciccozzi, M., Campitelli, L., Coco, A. L., Aquaro, S., Perno, C. F., Ciotti, M. 2009. Identification of the novel KI polyomavirus in paranasal and lung tissues. J Med. Virol. 81: 558-561. doi: 10.1002/jmv.21417

Babakir-Mina, M., Ciccozzi, M., Presti, A. L., Francesco Greco, F., Carlo Federico Perno, C. F., and Ciotti, M. 2010. Identification of Merkel Cell Polyomavirus in the lower respiratory tract of Italian patients. J Med. Virol. 82: 505-509. doi: 10.1002/jmv.21711

Bennett, S. M., Jiang, M., and Imperiale, M. J. 2013. Role of cell-type-specific endoplasmic reticulum-associated degradation in polyomavirus trafficking. J Virol. 87: 8843-8852. doi:10.1128/JVI.00664-13

Bennett, S. M., Zhao, L., and Imperiale, M. J. 2015. Role of a nuclear localization signal on the minor capsid proteins VP2 and VP3 in BKPyV nuclear entry.Virology 474: 110-116. doi:10.1016/j.virol.2014.10.013.

Bhattacharjee, S. 2015. Recent advances in Host-Virus Interactomics during entry and infection. Viral Adapt. Treat. 7: 57-66. doi: http://dx.doi.org/10.2147/VAAT.S60265

Bialasiewicz, S., Lambert, S. B., Whiley, D. M., Nissen, M. D., and Sloots, T. P. 2009. Merkel cell polyomavirus DNA in respiratory specimens from children and adults. Emerg. Infect. Dis. 15: 492-494. doi: 10.3201/eid1503.081067

Bialasiewicz, S., Whiley, D. M., Lambert, S. B., Jacob, K., Bletchly, C., Wang, D., Nissen, M. D., and Sloots, T. P. 2008. Presence of the newly discovered human polyomaviruses KI and WU in Australian patients with acute respiratory tract infection. J Clin. Virol. 41: 6368. doi: 10.1016/j.jcv.2007.11.001

Borowiec, J. A., Dean, F. B., Bullock, P. A., and Hurwitz, J. 1990. Binding and unwinding-how $\mathrm{T}$ antigen engages the SV40 origin of DNA replication. Cell 60: 181-184. PMID: 2153460 
Breau, W. C., Atwood, W. J., and Norkin, L. C. 1992. Class I major histocompatibility proteins are an essential component of the simian virus 40 receptor. J Virol 66: 2037-2045. PMID: 1312619

Brodsky, J. L., and Pipas, J. M. 1998. Polyomavirus T antigens: molecular chaperones for multiprotein complexes. J Virol.72: 5329-5334. PMID: 9620985

Brown, P., Tsai, T., and Gajdusek, D. C. 1975. Seroepidemiology of human Papovaviruses. Am. J Epidem. 102: 331-340. PMID: 233851

Bruckner, A., Stadlbauer, F., Guarino, L. A., Brunahl, A., Schneider, C., Rehfuess, C., Prives, C., Fanning, E., and Nasheuer, H. P. 1995. The mouse DNA polymerase $\alpha$ - primase subunit p48 mediates species-specific replication of polyomavirus DNA in vitro. Mol. Cell. Biol. 15: 1716-1724. PMID: 7862163

Buck, C. B., Van Doorslaer, K., Peretti, A., Geoghegan, E. M., Tisza, M. J., An, P., Katz, J. P., Pipas, J. M., McBride, A. A., Camus, A. C., McDermott, A. J., Dill, J. A., Delwart, E., Ng, T. F. F., Farkas, K., Austin, C., Kraberger, S., Davison, W., Pastrana, D. V., and Varsani, A. 2016. The ancient evolutionary history of Polyomaviruses. PLoS Pathog. 12: e1005574. doi:10.1371/journal.ppat.1005574.

Buck, C. B., Phan, G. Q., Raiji, M. T., Murphy, P. M, McDermott, D. H., and McBride, A. A. 2012. Complete genome sequence of a tenth human polyomavirus. J. Virol. 86: 10887.doi: 10.1128/JVI.01690-12.

Bullock, P. A. 1997. The initiation of simian virus 40 DNA replication in vitro. Crit. Rev. Biochem. Mol. Biol. 32: 503-568. doi: 10.3109/10409239709082001

Butin-Israeli, V., Ben-nun-Shaul, O., Kopatz, I., Adam, S. A., Shimi, T., Goldman, R. D., and Oppenheim, A. 2011. Simian virus 40 induces lamin A/C fluctuations and nuclear envelope deformation during cell entry. Nucleus 2: 320-330. doi: 10.4161/nucl.2.4.16371

Cahan, L. D., Singh, R., and Paulson, J. C. 1983. Sialyloligosaccharide receptors of binding variants of polyoma virus.Virology 130: 281-289. PMID: 6316632 
Cavaldesi M., Caruso M., Sthandier O., Amati P., and Garcia M. I. 2004. Conformational changes of murine polyomavirus capsid proteins induced by sialic acid binding. J Biol. Chem. 279: 41573-41579. doi: 10.1074/jbc.M405995200

Challberg, M. D., and Kelly, T. J. 1989. Animal virus DNA replication. Annu. Rev.Biochem. 58: 671-717. doi: 10.1146/annurev.bi.58.070189.003323

Chang, D., Fung, C-Y., Ou, W-C., Chao, P-C., Li, S-Y., Wang, M., Huang, Y-L., Tzeng, T-Y., and Tsai, R-T. 1997. Self-assembly of the JC virus major capsid protein, VP1, expressed in insect cells. J Gen. Virol. 78: 1435-1439. doi: 10.1099/0022-1317-78-6-1435

Chapagain, M. L., Verma, S., Mercier, F., Yanagihara, R., and Nerurkar, V. R. 2007. Polyomavirus JC infects human brain microvascular endothelial cells independent of serotonin receptor 2A. Virology 364: 55-63. doi: 10.1016/j.virol.2007.02.018

Chen, P. L., Wang, M., Ou, W. C., Lii, C. K., Chen, L. S., and Chang, D. 2001: Disulfide bonds stabilize JC virus capsid-like structure by protecting calcium ions from chelation. FEBS Lett. 500: 109-113. PMID: 11445066

Chromy, L. R., Pipas, J. M., and Garcea, R. L. 2003. Chaperone-mediated in vitro assembly of Polyomavirus capsids. PNAS 100: 10477-1082. doi: 10.1073/pnas.1832245100

Clayson, E. T., Brando, L. V. J., and Compans, R. W. 1989. Release of simian virus 40 virions from epithelial-cells is polarized and occurs without cell-lysis. J. Virol. 63: 2278-2288. PMCID: PMC250646

Cohen, S., Au, S., and Pante, N. 2011. How viruses access the nucleus. Biochim. Biophysic. Acta 1813: 1634-1645. http://dx.doi.org/10.1016/j.bbamcr.2010.12.009

Cui, X., Wang, J. C., Deckhut, A., Joseph, B. C., Eberwein, P., Cubitt, C. L., Ryschkewitsch, C. F., Agostini, H. T., and Stoner, G. L. 2004. Chinese strains (Type 7) of JC virus are AfroAsiatic in origin but are phylogenetically distinct from the Mongolian and Indian strains (Type 2D) and the Korean and Japanese strains (Type 2A). J. Mol. Evol. 58: 568-583. doi: $10.1007 / \mathrm{s} 00239-003-2579-2$ 
Dalianis, T., and Hirsch, H. H. 2013. Human polyomaviruses in disease and cancer. Virology 437: 63-72. doi: http://dx.doi.org/10.1016/j.virol.2012.12.015.

Damm, E. M., Pelkmans, L., Kartenbeck, J., Mezzacasa, A., Kurzchalia, T., and Helenius, A. 2005. Clathrin- and caveolin-1-independent endocytosis: entry of simian virus 40 into cells devoid of caveolae. J Cell Biol. 168: 477-488. doi:10.1083/jcb.200407113

Dangoria, N. S., Breau, W.C., Anderson, H. A., Cishek, D. M., and Norkin, L. C. 1996. Extracellular simian virus 40 induces an ERK/MAP kinase independent signalling pathway that activates primary response genes and promotes virus entry. J. Gen. Virol. 77: 2173-2182. doi: 10.1099/0022-1317-77-9-2173

Daniels, R., Rusan, N. M., Wadsworth, P., and Hebert, D. N., 2006a. SV40 VP2 and VP3 insertion into ER membranes is controlled by the capsid protein VP1: implications for DNA translocation out of the ER. Mol. Cell 24: 955-966. doi: 10.1016/j.molcel.2006.11.001

Daniels, R., Rusan, N. M., Wilbuer, A. K., Norkin, L. C., Wadsworth, P., and Hebert, D. N., 2006b. Simian virus 40 late proteins possess lytic properties that render them capable of permeabilizing cellular membranes. J. Virol. 80: 6575-6587. doi: 10.1128/JVI.00347-06

Daniels, R., Sadowicz, D., and Hebert, D. N. 2007. A very late viral protein triggers the lytic release of SV40. PLoS Pathog. 3: e98. doi:10.1371/journal.ppat.0030098

Deb, S., De Lucia, A. L., Baur, C. P., Koff, A., and Tegtmeyer, P. 1986. Domain structure of the Simian Virus 40 core origin of replication. Mol. Cell. Biol. 6: 1663-1670. PMID: 3023900

Deb, S., Tsui, S., Koff, A., De Lucia, A. L., Parsons, R., and Tegtmeyer, P. 1987. The T-antigen binding domain of the simian virus 40 core origin of replication. J Virol. 61: 2143-2149.

Dorries, K., Vogel, E., Gunther, S., and Czub, S. 1994. Infection of human polyomaviruses JC and $\mathrm{BK}$ in peripheral blood leucucytes from immunocompetent individuals. Virology 198: 59-70. doi: 10.1006/viro.1994.1008 
Drachenberg, C. B., Hirsch, H. H., Ramos, E., and Papadimitriou, J. C. 2005. Polyomavirus disease in renal transplantation. Review of pathological findings and diagnostic methods. Hum. Pathol. 36: 1245-1255. doi: 10.1016/j.humpath.2005.08.009

Dugan, A. S., Eash, S., and Atwood, W. J. 2005. An N-linked glycoprotein with alpha (2,3)linked sialic acid is a receptor for BK virus. J Virol. 79: 14442-14445.doi: 10.1128/JVI.79.22.14442-14445.2005

Dugan, A. S., Eash, S., and Atwood, W. J.2006. Update on BK virus entry and intracellular trafficking. Transpl. Infect. Dis. 8: 62-67.doi: 10.1111/j.1399-3062.2006.00153.x

Duncavage, E. J., Zehnbauer, B. A., and Pfeifer, J. D. 2009. Prevalence of Merkel cell polyomavirus in Merkel cell carcinoma. Mod. Pathol. 22: 516521.doi:10.1038/modpathol.2009.3

Eash, S., and Atwood, W. J. 2005. Involvement of cytoskeletal components in BK virus infectious entry. J. Virol. 79: 11734-11741. doi: 10.1128/JVI.79.18.11734-11741.2005

Eash, S., Querbes, W., and Atwood, W. J. 2004. Infection of Vero cells by BK virus is dependent on caveolae. J. Virol. 78: 11583-11590. doi: 10.1128/JVI.78.21.11583-11590.2004

Elphick, G. F., Querbes, W., Jordan, J. A., Gee, G. V., Eash, S., Manley, K., Dugan, A., Stanifer, M., Bhatnagar, A., Kroeze, W. K., Roth, B. L., and Atwood, W. J. 2004. The human polyomavirus, JCV, uses serotonin receptors to infect cells. Science 306: 1380-1383. doi: $10.1126 /$ science. 1103492

Erickson, K. D., Bouchet-Marquis, C., Heiser, K., Szomolanyi-Tsuda, E., Mishra, R., Lamothe, B., Hoenger, A., and Garcea, R. L. 2012. Virion assembly factories in the nucleus of Polyomavirus-infected cells. PLoS Pathog. 8: e1002630. doi:10.1371/journal.ppat.1002630

Erickson, K. D., Garcea, R. L., and Tsai, B. 2009. Ganglioside GT1b is a putative host cell receptor for the Merkel Cell Polyomavirus. J Virol. 83: 1027510279.doi:10.1128/JVI.00949-09 
Evans, G. L., Caller, L. G., Foster, V., and Crump, C. M. 2015. Anion homeostasis is important fornon-lytic release of BK polyomavirusfrom infected cells. Open Biol. 5: 150041. doi: http://dx.doi.org/10.1098/rsob.150041

Fanning, E., and Baumgartner, I. 1980. Role of fast sedimenting SV40 nucleoprotein complexes in virus assembly. Virology 102: 1-12. PMID: 6245498

Fanning, E., Zhao, X. and Jiang, X. 2009. Polyomavirus life cycle. In DNA Tumor Viruses. Edited by B. Damania and J. M. Pipas. Springer Science, NY, USA.

Fay, N., and Pante, N. 2015. Nuclear entry of DNA viruses. Front. Microbiol. 6: 467.doi: 10.3389/fmicb.2015.00467.

Feng, H., Shuda, M., Chang, Y., and Moore, P. S. 2008. Clonal integration of a polyomavirus in human Merkel cell carcinoma. Science 319: 1096-1100. doi: 10.1126/science.1152586

Foulongne, V., Brieu, N., Jeziorski, E., Chatain, A., Rodiere, M., and Segondy, M. 2008. KI and WU polyomaviruses in children, France. Emerg. Infect. Dis. 14: 523-525. doi: $10.3201 /$ eid1403.071206

Fricks, C. E., and Hogles, J. M. 1990. Cell-induced conformational change in poliovirus: externalization of the amino terminus of VP1 is responsible for liposome binding. J Virol. 64: 1934-1945. PMCID: PMC249347

Fried, H., Cahan, L. D., and Paulson, J. C. 1981. Polyomavirus recognizes specific sialyloligosaccharide receptors on host cells. Virology 109: 188-192. PMID: 6258307

Fulcher, A. J., and Jans, D. A. 2011. Regulation of nucleocytoplasmic trafficking of viral proteins: an integral role in pathogenesis? Biochim. Biophys. Acta 1813: 2176-2190. doi:10.1016/j.bbamcr.2011.03.019.

Goh, S., Lindau, C., Tiveljung-Lindell, A., and Allander, T. 2009. Merkel cell polyomavirus in respiratory tract secretions. Emerg. Infect. Dis. 15: 489-491. doi: 10.3201/eid1503.081206

Gai, D., Li, D., Finkielstein, C. V., Ott, R. D., Taneja, P., Fanning, E., and Chen, X. S. 2004. Insights into the oligomeric states, conformational changes, and helicase activities of 
SV40 large tumor antigen. J Biol. Chem. 279: 38952-38959. doi: 10.1074/jbc.M406160200

Garber, E. A., Seidman, M. M., and Levine, A. J. 1980. Intracellular SV40 nucleoprotein complexes: synthesis to encapsidation. Virology 107: 389-401. PMID: 6256939

Gardner, S. D., Field, A. M., Coleman, D. V., and Hulme, B. 1971. New human papovavirus (BK) isolated from urine after renal transplantation. Lancet 1: 1253-1257. PMID: 4104714

Gardner, S. D., Mackenzie, E. F. D., Smith, C., and Porter, A. A. 1984. Prospective study of the human Polyomaviruses BK and JC and Cytomegaloviruses in renal transplant recipients. J. Clin. Path. 37: 578-586. PMID: 6327777

Gaynor, A. M., Nissen, M. D., Whiley, D. M., Mackay, I. M., Lambert, S. B., Wu, G., Brennan, D. C., Storch, G. A., Sloots, T. P., and Wang D. 2007. Identification of a novel polyomavirus from patients with acute respiratory tract infections. PLoS Pathog. 3: e64. doi: 10.1371/journal.ppat.0030064

Gerits, N., and Moens, U. 2012. Agnoprotein of mammalian polyomaviruses. Virology 432: 316326. doi: http://dx.doi.org/10.1016/j.virol.2012.05.024

Giraud G, Ramqvist T, Pastrana DV, Pavot V, Lindau C, Kogner P, Orrego, A., Buck, C. B., Allander, T., Holm, S., Gustavsson, B., and Dalianis, T. 2009. DNA from KI, WU and Merkel Cell Polyomaviruses is not detected in childhood central nervous system tumours or neuroblastomas. PLoS One 4: e8239. doi:10.1371/journal.pone.0008239

Giraud, G., Ramqvist, T., Ragnarsson-Olding, B., and Dalianis, T. 2008. DNA from BK Virus and JC Virus and from KI, WU, and MC Polyomaviruses as well as from Simian Virus 40 is not detected in non-UV-light-associated primary malignant melanomas of mucous membranes. J Clin. Microbiol. 46: 3595-3598. doi:10.1128/JCM.01635-08

Goodwin, E. C., Lipovsky, A., Inoue, T., Magaldi, T. G., Edwards, A. P., Van Goor, K. E., Paton, A. W., Paton, J. C., Atwood, W. J., Tsai, B., and DiMaio, D. 2011. BiP and 
multiple DNAJ molecular chaperones in the endoplasmic reticulum are required for efficient simian virus 40 infection. mBio 2: e00101-00111. doi: 10.1128/mBio.00101-11

Gosert, R., Kardas, P., Major, E. O., and Hirsch, H. H. 2010. Rearranged JC virus noncoding control regions found in progressive multifocal leukoencephalopathy patient samples increase virus early gene expression and replication rate. J Virol. 84: 10448-10456. doi:10.1128/JVI.00614-10.

Gosert, R., Rinaldo, C. H., Funk, G. A., Egli, A., Ramos, E., Drachenberg, C. B., and Hirsch, H. H. 2008. Polyomavirus BK with rearranged noncoding control region emerge in vivo in renal transplant patients and increase viral replication and cytopathology. J Exp. Med. 205: 841-852. doi/10.1084/jem.20072097.

Greenlee, J. E. 1997. Polyomavirus. In Clinical Virology. Edited by D. D. Richman, R. J. Whitley, and F. G. Hayden. Churchil Livingstone Inc. NY. USA. pp 549-567.

Hale, A. D., Bartkeviciute, D., Dargeviciute, A., Jin, L., Knowles, W., Staniulis, J., Brown, D. W., and Sasnauskas, K. 2002. Expression and antigenic characterization of the major capsid proteins of human polyomaviruses BK and JC in Saccharomyces cerevisiae. J Virol. Methods 104: 93-98. doi: 10.1016/S0166-0934(02)00036-8

Han, T. H., Chung, J. Y., Koo, J. W., Kim, S. W., and E. S. Hwang, E. S. 2007. WU polyomavirus in children with acute lower respiratory tract infections, South Korea. Emerg. Infect. Dis. 13: 1766-1768. doi: 10.3201/eid1311.070872

Haycox, C. L., Kim, S., Fleckman, P., Smith, L. T., Piepkorn, M., Sundberg, J. P., Howell, D. N., and Miller, S. E. 1999. Trichodysplasia spinulosa - a newly described folliculocentric viral infection in an immunocompromised host. J Invest. Dermatol. Symp. Proc. 4: 268271..doi: http://dx.doi.org/10.1038/sj.jidsp.5640227

Heaphy Jr., M. R., Shamma, H. N., Hickmann, M., and White, M. J. 2004. Cyclosporine-induced folliculodystrophy. J Am. Acad. Dermatol. 50: 310-315. doi: 10.1016/S0190

Heritage, J., Chesters, P. M., and McCance, D. J. 1981. The persistence of papovavirus BK DNA sequences in normal human renal tissue. J Med. Virol. 8: 143-150. PMID: 6271922 
Hirsch, H. H. 2002. Polyomavirus BK nephropathy: a (re-)emerging complication in renal transplantation. Am. J Transplant. 2: 25-30. PMID: 12095052

Ho, J., Jedrych, J. J., Feng, H., Natalie, A. A., Grandinetti, L., Mirvish, E., Crespo, M. M., Yadav, D., Fasanella, K. E., Proksell, S., Kuan, S-F., Pastrana, D. V., Buck, C. B., Shuda, Y., Moore, P. S., and Chang, Y. 2015. Human Polyomavirus 7-associated pruritic rash and viremia in transplant recipients. J Infect. Dis. 211: 1560-1565. doi: 10.1093/infdis/jiu524

Houben, R., Adam, C., Baeurle, A., Hesbacher, S., Grimm, J., Angermeyer, S., Henzel, K., Hauser, S., Elling, R., Brocker, E. B., Gaubatz, S., Becker, J. C., and Schrama, D. 2012. An intact retinoblastoma protein-binding site in Merkel cell polyomavirus large $\mathrm{T}$ antigen is required for promoting growth of Merkel cell carcinoma cells. Int. J. Cancer. 130: 847856. doi: $10.1002 / \mathrm{ijc} .26076$

Huang, S. G., Weisshart, K., Gilbert, I., and Fanning, E. 1998. Stoichiometry and mechanism of assembly of SV40 T antigen complexes with the viral origin of DNA replication and DNA polymerase alpha-primase. Biochemistry 37: 15345-15352. doi: $10.1021 /$ bi9810959

Huang, Y-L., Wang, M., Ou, W-C., Fung, C-Y., Chen, L-S., and Chang, D. 2001. Analysis of DNA-binding activity of the JC virus minor capsid protein VP2. J Neurovirol. 9: 21-24.

Hurwitz, J., Dean, F. B., Kwong, A. D., and Lee, S. H. 1990. The in vitro replication of DNA containing the SV40 origin. J Biol. Chem. 265: 18043-18046.

Inoue, T., and Tsai, B. 2013. How viruses use the endoplasmic reticulum for entry, replication, and assembly. Cold Spring Harb. Perspect. Biol. 5: a013250. doi: $10.1101 /$ cshperspect.a013250

Inoue, T., and Tsai, B. 2011. A large and intact viral particle penetrates the endoplasmic reticulum membrane to reach the cytosol. PLoS Pathog. 7: e1002037. doi: http://dx.doi.org/10.1371/journal.ppat.1002037 
Jackson, W. T., Giddings, T. H., Jr, Taylor, M. P., Mulinyawe, S., Rabinovitch, M., Kopito, R.R., and Kirkegaard, K. 2005.Subversion of cellular autophagosomal machinery by RNA viruses. PLoS Biol. 3: e156. doi: 10.1371/journal.pbio.0030156.

Jiang, M., Abend, J. R., Tsai, B., and Imperiale, M. J. 2009. Early events during BK virus entry and disassembly. J Virol. 83: 1350-1358.doi:10.1128/JVI.02169-08

Jiang, X., Klimovich, V., Arunkumar, A. I., Hysinger, E. B., Wang, Y., Ott, R. D., Guler, G. D., Weiner, B., Chazin, W. J., and Fanning, E. 2006. Structural mechanism of RPA loading on DNA during activation of a simple pre-replication complex. EMBO J 25: 5516-5526. doi: $10.1038 /$ sj.emboj. 7601432

Jin, L. 1993. Rapid genomic typing of BK virus directly from clinical specimens. Mol. Cell. Probes 7: 331-334. doi: 10.1006/mcpr.1993.1047

Jin, L., Gibson, P. E., Booth, J. C., and Clewly, J. P. 1993. Genomic typing of BK virus in clinical specimens by direct sequencing of polymerase chain reaction products. $\mathrm{J}$ Med. Virol. 41: 11-17. PMID: 8228931

Kartenbeck, J., Stukenbrok, H., and Helenius, A. 1989. Endocytosis of simian virus 40 into the endoplasmic reticulum. J Cell Biol. 109: 2721-2729. PMID: 2556405

Kasamatsu, H., and Nakanishi, A. 1998. How do animal DNA viruses get to the nucleus? Annu. Rev. Microbiol. 52: 627-686. doi: 10.1146/annurev.micro.52.1.627

Kassem, A., Technau, K., Kurz, A. K., Pantulu, D., Loning, M., Kayser, G., Stickeler, E., Weyers, W., Diaz, C., Werner, M., Nashan, D., and Zur Hausen, A. 2009. Merkel cell polyomavirus sequences are frequently detected in nonmelanoma skin cancer of immunosuppressed patients. Int. J Can. 125: 356-361. doi: 10.1002/ijc.24323

Kean, J. M., Rao, S., Wang, M., and Garcea, R. L. 2009. Seroepidemiology of human Polyomaviruses. PLoS Path. 5: e1000363. doi: 10.1371/journal.ppat.1000363

Kelly, T. J., Wold, M. S., and Li, J. 1988. Initiation of viral DNA replication. Adv. Virus Res. 34: $1-42$. 
Kiasari, B. A., Vallely, P. J., Corless, C. E., Al-Hammadi, M., and Klapper, P. E. 2008. Agerelated pattern of KI and WU polyomavirus infection. J Clin. Virol. 43: 123-125. doi: $10.1016 / \mathrm{j} . j \mathrm{jcv} .2008 .05 .003$

Kilcher, S., and Mercer, J. 2014. Next generation approaches to study virus entry and infection. Curr Opin Virol. 4: 8-14. doi: 10.1016/j.coviro.2013.10.002

Komagome, R., Sawa, H., Suzuki, T., Suzuki, Y., Tanaka, S., Atwood, W. J., and Nagashima, K. 2002. Oligosaccharides as receptors for JC virus. J. Virol. 76: 12992-13000. doi: 10.1128/JVI.76.24.12992-13000.2002

Korup, S., Rietscher, J., Calvignac-Spencer, S., Trusch, F., Hofmann, J., Moens, U., Sauer, I., Voigt, S., Schmuck, R., and Ehlers, B. 2013. Identification of a novel human Polyomavirus in organs of the gastrointestinal tract. PLoS ONE 8: e58021. doi:10.1371/journal.pone.0058021.

Kuksin, D., and Norkin, L. C. 2012. Disassociation of the SV40 genome from capsid proteins prior to nuclear entry.Virology J 9: 158. doi: 10.1186/1743-422X-9-158

Kwun, H. J., Guastafierro, A., Shuda, M., Meinke, G., Bohm, A., Moore, P. S., and Chang, Y. 2009. The minimum replication origin of Merkel Cell Polyomavirus has a unique Large $\mathrm{T}$-antigen loading architecture and requires small T-antigen expression for optimal replication. J Virol. 83: 12118-12128. doi: 10.1128/JVI.01336-09

Kwun, H. J., Shuda, M., Feng, H., Camacho, C. J., Moore, P. S., and Chang, Y. 2013. Merkel Cell Polyomavirus small $\mathrm{T}$ antigen controls viral replication and oncoprotein expression by targeting the cellular ubiquitin ligase $\mathrm{SCF}^{\mathrm{Fbw} 7}$. Cell Host Microbe 14: 125-135. doi:10.1016/j.chom.2013.06.008.

Lange, A. Mills, R. E., Lange, C. J., Stewart, M., Devine, S. E., and Corbett, A. H. 2007. Classical nuclear localization signals: definition, function, and interaction with importin alpha. J. Biol. Chem. 282: 5101-5105. doi: 10.1074/jbc.R600026200 
Lange, A., Mclane, L. M., Mills, R. E., Devine, S. E., and Corbett, A. H. 2010. Expanding the definition of the classical bipartite nuclear localization signal. Traffic 11: 311-323. doi:10.1111/j.1600-0854.2009.01028.x

Le, B. M., Demertzis, L. M., Wu, G., Tibbets,R. J., Buller,R., Arens, M. Q., Gaynor, A. M., Storch, G. A., and Wang, D. 2007. Clinical and epidemiologic characterization of WU polyomavirus infection, St. Louis, Missouri. Emerg. Infect. Dis. 13: 19361938.doi: $10.3201 /$ eid1312.070977

Lee, J. S. S., Frederiksen, P., and Kossard, S. 2008. Progressive trichodysplasia spinulosa in a patient with chronic lymphocytic leukaemia in remission. Australas. J Dermatol. 49: 5760. doi: 10.1111/j.1440-0960.2007.00422.x

Li, T-C., Takeda, N., Kato, K., Nilsson, J., Xing, L., Haag, L., Cheng, R. H., and Miyamura, T. 2002. Characterization of self-assembled virus-like particles of human polyomavirus BK generated by recombinant baculoviruses. Virology 311: 115-124. doi:10.1016/S00426822(03)00141-7

Lim, E. S., Reyes, A., Antonio, M., Saha, D., Ikumapayi, U. N., Adeyemi, M., Stine, O. C., Skelton, R., Brennan, D. C., Mkakosya, R. S., Manary, M. J., Gordon, J. I., and Wang, D. 2013. Discovery of STL polyomavirus, a polyomavirus of ancestral recombinant origin that encodes a unique $\mathrm{T}$ antigen by alternative splicing. Vrology 436: 295-303. doi: 10.1016/j.virol.2012.12.005

Liu, X., Hein, J., Richardson, S. C. W., Basse, P. H., Toptan, T., Moore, P. S., Gjoerup, O. V., and Chang, Y. 2011. Merkel Cell polyomavirus large T antigen disrupts lysosome clustering by translocating human Vam6p from the cytoplasm to the nucleus. J Biol. Chem. 286: 17079-17090. doi:10.1074/jbc.M110.192856

Liu, C.K., Wei, G., and Atwood, W. J. 1998. Infection of glial cells by the human polyomavirus JC is mediated by an N-linked glycoprotein containing terminal alpha (2-6)-linked sialic acids. J Virol. 72: 4643-4649. PMID: 9573227 
Low, J. A., Magnuson, B., Tsai, B. and Imperiale, M. J. 2006. Identification of gangliosides GD1b and GT1b as receptors for BK Virus. J Virol. 80: 1361-1366. doi:10.1128/JVI.80.3.1361-1366.2006

MacKay, R. L., and R. A. Consigli. 1976. Early events in polyomavirus infection: attachment, penetration, and nuclear entry. J. Virol. 19: 620-636.

Magnuson, B., Rainey, E. K., Benjamin, T., Baryshev, M., Mkrtchian, S., and Tsai, B. 2005. ERp29 triggers a conformational change in Polyomavirus to stimulate membrane binding. Mol. Cell. 20: 289-300. doi: 10.1016/j.molcel.2005.08.034

Major, E. O. 2010. Progressive multifocal leukoencephalopathy in patients on immunomodulatory therapies. Annu. Rev. Med. 61: 35-47. doi: 10.1146/annurev.med.080708.082655

Marfori, M., Mynott, A., Ellis, J. J., Mehdi, A. M., Saunders, N. F., Curmi, P. M., Forwood, J. K., Boden, M., and Kobe, B. 2011. Molecular basis for specificity of nuclear import and prediction of nuclear localization. Biochim. Biophys. Acta 1813: 1562-1577. doi: 10.1016/j.bbamcr.2010.10.013.

Marsh, M., and Helenius, A. 2006. Virus entry: open sesame. Cell 124: 729-740. doi: 10.1016/j.cell.2006.02.007

Mattern, C. F. T., Takemoto, K. K., and Daniel, W. A. 1966. Replication of polyoma virus in mouse embryo cells: electron microscopic observations.Virology 30: 242-256. PMID: 4288278

Meijden, Van der, E., Janssens, R. W. A., Lauber, C., BouwesBavinck, J. N., Gorbalenya, A. E., and Feltkamp, M. C. W. 2010. Discovery of a new human Polyomavirus associated with Trichodysplasia spinulosa in an immunocompromized patient. PLoS Pathog. 6: e1001024. doi:10.1371/journal.ppat.1001024

Mishra, N., Pereira, M., Rhodes, R. H. An, P., Pipas, J. M. Jain, K. Kapoor, A., Briese, T., Faust, P. L., and Lipkin, W. I. 2014. Identification of a novel polyomavirus in a 
pancreatic transplant recipient with retinal blindness and vasculitic myopathy. J Infect. Dis. 210: 1595-1599. doi: 10.1093/infdis/jiu250

Mkrtchian, S., Fang, C., Hellman, U. and Ingelman-Sundberg, M. 1998. A stress-inducible rat liver endoplasmic reticulum protein, ERp29. Eur. J. Biochem. 251: 304-313. PMID: 9492298

Montross, L., Watkins, S., Moreland, R. B., Mamon, H., Caspar, D. L. D. and Garcea, R. L. 1991. Nuclear assembly of polyomavirus capsids in insect cells expressing the major capsid protein VP1. J Virol. 65: 4991-4998. PMID: 1651418

Moriyama, T., Marquez, J. P., Wakatsuki, T., and Sorokin, A. 2007. Caveolar endocytosis is critical for BK virus infection of human renal proximal tubular epithelial cells. J Virol. 81: 8552-8562. doi: 10.1128/JVI.00924-07

Mudhakir, D., and Harashima, H. 2009. Learning from the viral journey: how to enter cells and how to overcome intracellular barriers to reach the nucleus. AAPS J. 11: 65-77.doi: $10.1208 / \mathrm{s} 12248-009-9080-9$.

Nakanishi, A., Li, P. P., Qu, Q., Jafri, Q. H., and Kasamatsu, H. 2007. Molecular dissection of nuclear entry-competent SV40 during infection. Virus Res. 124: 226-230. doi: 10.1016/j.virusres.2006.10.001

Nakanishi, A., Shum, D., Morioka, H., Otsuka, E., and Kasamatsu, H. 2002. Interaction of the Vp3 nuclear localization signal with the importin alpha 2/beta heterodimer directs nuclear entry of infecting simian virus 40. J Virol 76: 9368-9377. PMID: 12186919

Neu, U., Maginnis, M. S., Palma, A. S., Stroh, L. J., Nelson, C. D., Feizi, T., Atwood, W. J., and Stehle, T. 2010. Structure-function analysis of the human JC polyomavirus establishes the LSTc pentasaccharide as a functional receptor motif. Cell Host Microb. 8: 309-319. doi: 10.1016/j.chom.2010.09.004

Neu, U., Hengel, H., Blaum, B. S., Schowalter, R. M., Macejak, D., Gilbert, M., Wakarchuk, W. W., Imamura, A., Ando, H., Kiso, M., Arnberg, N., Garcea, R. L., Peters, T., Buck, C. B., and Stehle, T. 2012. Structures of Merkel Cell Polyomavirus VP1 complexes define a 
sialic acid binding site required for infection. Plos Pathog. 8: e1002738. doi:10.1371/journal.ppat.1002738

Nguyen, K. D., Lee, E. E., Tyring, S. K., North, J. P., Cockerell, C. J., Buck, C. B., and Wang, R. C. 2016. LB806 A novel strain of HPyV7 causing a HIV/AIDS-associated pruritic rash. J Invest. Dermatol. 136:, B10. doi: http://dx.doi.org/10.1016/j.jid.2016.05.060

Norkin, L. C., Anderson, H. A., Wolfrom, S. A., and Oppenheim, A. 2002. Caveolar endocytosis of simian virus 40 is followed by brefeldin A-sensitive transport to the endoplasmic reticulum, where the virus disassembles. J Virol 76: 5156-5166. doi: 10.1128/JVI.76.10.5156-5166.2002

Oh, P., McIntosh, D. P., and Schnitzer, J. E. 1998. Dynamin at the neck of caveolae mediates their budding to form transport vesicles by GTP-driven fission from the plasma membrane of endothelium. J Cell Biol. 141: 101-114. PMID: 9531551

Osswald, S. S., Kulick, K. B., Tomaszewski, M.M., and Sperling, L. C. 2007. Viral-associated trichodysplasia in a patient with lymphoma: a case report and review. J Cutan. Path. 34: 721-725. doi: 10.1111/j.1600-0560.2006.00693.x

Padgett, B. L., and Walker, D. L. 1973. Prevalence of antibodies in human sera against JC virus, an isolate from a case of progressive multifocal leucoencephalopathy. J Infect. Dis. 127: 476-470. PMID: 4571704

Padgett, B. L., Walker, D. L., ZuRhein, G., Echroade, R., and Dessel, B. 1971. Cultivation of papova-like virus from human brain with progressive multifocal leukoencephalopathy. Lancet 1: 1257-1260. PMID: 4104715

Pante, N., and Kann, M. 2002. Nuclear pore complex is able to transport macromolecules with diameters of about $39 \mathrm{~nm}$. Mol. Biol. Cell 13: 425-434. doi: 10.1091/mbc.01-06-0308

Parton, R. G., and Simons, K. 2007. The multiple faces of caveolae. Nat. Rev. Mol. Cell Biol. 8: 185-194. doi:10.1038/nrm2122

Parton, R.G., and Richards, A. A. 2003. Lipid rafts and caveolae as portals for endocytosis: new insights and common mechanisms. Traffic 4: 724-738. PMID: 14617356 
Pastrana, D. V., Ray, U., Magaldi, T. G., Schowalter, R. M., Çuburu, N., and Buck, C. B. 2013. BK polyomavirus genotypes represent distinct serotypes with distinct entry tropism. J Virol. 87: 10105-10113. doi: 10.1128/JVI.01189-13

Pavesi, A. 2003. African origin of Polyomavirus JC and implications for prehistoric human migrations. J. Mol. Evol. 56: 564-572. doi: 10.1007/s00239-002-2425-y

Payungporn, S., Chieochansin, T., Thongmee, C., Samransamruajkit, R., Theamboolers, A., and Poovorawan, Y. 2008. Prevalence and molecular characterization of WU/KI polyomaviruses isolated from pediatric patients with respiratory disease in Thailand. Virus Res. 135: 230-236. doi: 10.1016/j.virusres.2008.03.018

Pelkmans, L., and Helenius, A. 2003. Insider information: what viruses tell us about endocytosis. Curr. Opin. Cell Biol. 15: 414-422. PMID: 12892781

Pelkmans, L., Kartenbeck, J., and Helenius, A. 2001. Caveolar endocytosis of simian virus 40 reveals a new two-step vesicular-transport pathway to the ER. Nat. Cell Biol. 3: 473-483. doi: $10.1038 / 35074539$

Pelkmans, L., Puntener, D., and Helenius, A. 2002. Local actin polymerization and dynamin recruitment in SV40-induced internalization of caveolae. Science 296: 535-539. doi: $10.1126 /$ science. 1069784

Pho, M. T., Ashok, A., and Atwood, W. J. 2000. JC Virus enters human glial cells by clathrin dependent receptor mediated endocytosis. J. Virol. 74: 2288-2292. PMID: 10666259

Primrose, S. B., and Dimmock, N. J. 1980. Tumor Viruses. In Introduction to Modern Virology. Blackwell Scientific Publications, pp 191-208.

Qu, Q., Sawa, H., Suzuki, T., Semba, S., Henmi, C., Okada, Y., Tsuda, M., Tanaka, S., Atwood, W. J., and Nagashima, K. 2004. Nuclear entry mechanism of the human polyomavirus JC virus-like particle. J Biol. Chem. 279: 27735-27742. doi: 10.1074/jbc.M310827200

Querbes, W., Benmerah, A., Tosoni, D., Di Fiore, P. P., and Atwood, W. J. 2004. A JC virusinduced signal is required for infection of glial cells by a clathrin- and eps15-dependent pathway. J Virol. 78: 250-256. PMID: 14671106 
Raghava, S., Giorda, K. M., Romano, F. B., Heuck, A. P., Hebert, D. N. 2011. The SV40 late protein VP4 is a viroporin that forms pores to disrupt membranes for viral release. PLoS Pathog. 7: e1002116. doi:10.1371/journal.ppat.1002116

Rainey-Barger, E. K., Magnuson, B., and Tsai, B., 2007. A chaperone-activated non enveloped virus perforates the physiologically relevant endoplasmic reticulum membrane. J Virol. 81: 12996-13004. doi: 10.1128/JVI.01037-07

Reese, D. K., Meinke, G., Kumar, A., Moine, S., Chen, K., Sudmeier, J. L., Bachovchin, W., Bohm, A., and Bullock, P. A. 2006. Analyses of the interaction between the origin binding domain from Simian Virus $40 \mathrm{~T}$ antigen and single stranded DNA provide insights into DNA unwinding and initiation of DNA replication. J Virol. 80: 12248 12259. doi: 10.1128/JVI.01201-06

Richterova, Z., Liebl, D., Horak, M., Palkova, Z., Stokrova, J., Hozak, P., Korb, J., and Forstova, J. 2001. Caveolae are involved in the trafficking of mouse polyomavirus virions and articial VP1 pseudocapsids toward cell nuclei. J Virol. 75: 10880-10891. doi: 10.1128/JVI.75.22.10880-10891.2001

Rothberg, K. G., Heuser, J. E., Donzell, W. C., Ying, Y. S., Glenney, J. R., and Anderson, R. G. 1992. Caveolin, a protein component of caveolae membrane coats. Cell 68: 673682. PMID: 1739974

Sadler, G. M., Halbert, A. R. Smith, N., and M. Rogers, M. 2007. Trichodysplasia spinulosa associated with chemotherapy for acute lymphocytic leukaemia. Aust. J Dermatol. 48: 110-114. doi: 10.1111/j.1440-0960.2007.00348.x

Salzman, N. P. (Ed) 1986. The Papovaviridae Volume 1: The Polyomaviruses. Plenum Press. Plenum Publishing Corporation, NY, USA.

Saribas, A. S., Mun, S., Johnson, J., El-Hajmoussa, M., White, M. K., and Safak. M. 2014. Human polyoma JC virus minor capsid proteins, VP2 and VP3, enhance large T antigen binding to the origin of viral DNA replication: evidence for their involvement in 
regulation of the viral DNA replication. Virology 449: 1-16. doi: 10.1016/j.virol.2013.10.031

Saribas, A. S., White, M. K., and Safak, M. 2012. JC virus agnoprotein enhances large T antigen binding to the origin of viral DNA replication: evidence for its involvement in viral DNA replication. Virology 433: 12-26. doi: 10.1016/j.virol.2012.06.017

Schelhaas, M., Malmstrom, J., Pelkmans, L., Haugstetter, J., Ellgaard, L., Grunewald, K., and Helenius, A. 2007. Simian virus 40 depends on ER protein folding and quality control factors for entry into host cells. Cell 131: 516-529. doi: 10.1016/j.cell.2007.09.038

Schowalter, R. M., and Buck, C. B. 2013. The Merkel Cell polyomavirus minor capsid protein. PLoS Pathog. 9: e1003558. doi:10.1371/journal.ppat.1003558

Schowalter, R. M., Pastrana, D. V., and Buck, C. B. 2011. Glycosaminoglycans and sialylated glycans sequentially facilitate Merkel Cell polyomavirus infectious entry. PLoS Pathog. 7: e1002161. doi:10.1371/journal.ppat.1002161.

Schowalter, R. M., Pastrana, D. V., Pumphrey, K. A., Moyer, A. L., and Buck, C. B. 2010. Merkel cell polyomavirus and two previously unknown polyomaviruses are chronically shed from human skin. Cell Host Microbe 7: 509-515. doi: 10.1016/j.chom.2010.05.006

Schowalter, R. M., Reinhold, W. C., and Buck, C. B. 2012. Entry tropism of BK and Merkel Cell polyomaviruses in cell culture. PLoS One 7: e42181. doi:10.1371/journal.pone.0042181

Schrama, D., Groesser, L, Selma Ugurel, S., Hafner, C.; Pastrana, D. V., Buck, C. B., Cerroni, L., Anna Theiler, A., and Becker, J. C. 2014. Presence of human polyomavirus 6 in mutation-specific BRAF inhibitor-induced epithelial proliferations. JAMA Dermatol. 150: 1180-1186. doi: 10.1001/jamadermatol.2014.1116

Schwieger-Briel, A., Balma-Mena, A., Ngan, B., Dipchand, A., and Pope, E. 2010. Trichodysplasia spinulosa - a rare complication in immunosuppressed patients. Pediatric Dermatol. 27: 509-513. doi: 10.1111/j.1525-1470.2010.01278.x

Scuda, N., Hofmann, J., Calvignac-Spencer, S., Ruprecht, K., Liman, P., Kuhn, J., Hengel, H., and Ehlers B. 2011. A novel human polyomavirus closely related to the African green 
monkey-derived lymphotropic polyomavirus. J Virol. 85: 4586-4590, 2011. doi: 10.1128/JVI.02602-10

Selinka, H-C., Giroglou, T., Nowak, T., Christensen, N. D., and Sapp, M. 2003. Further evidence that Papillomavirus capsids exist in two distinct conformations. J. Virol. 77: 12961-12967. doi: 10.1128/JVI.77.24.12961-12967.2003

Shah, K. V., Daniel, R. W., and Warszawski, R. M. 1973. High prevalence of antibodies to BK virus, an SV40 related papovavirus, in residents of Maryland. J Infect. Dis. 128: 784-787. PMID: 4587749

Sharp, C. P., Norja, P., Anthony, I., Bell, J. E., and Simmonds, P. 2009. Reactivation and mutation of newly discovered WU, KI, and Merkel cell carcinoma polyomaviruses in immunosuppressed individuals. J Infect. Dis. 199: 398-404. doi: 10.1086/596062

Shishido-Hara, Y., Ichinose, S., Higuchi, K., Hara, Y., and Yasui, K. 2004. Major and minor capsid proteins of human Polyomavirus JC cooperatively accumulate to nuclear domain 10 for assembly into virions. J Virol. 78: 9890-9903. doi: 10.1128/JVI.78.18.98909903.2004

Siebrasse, E. A., Nguyen, N. L., Willby, M. J., Erdman, D. D., Menegus, M. A., Wang, D. 2016. Multiorgan WU polyomavirus infection in bone marrow transplant recipient. Emerg. Infect. Dis. 22: 24-31. Doi: http://dx.doi.org/10.3201/eid2201.151384

Siebrasse, E. A., Reyes, A., Lim, E.S., Zhao, G., Mkakosya, R. S., Manary, M. J, Gordon, J. I., and Wanga, D. 2012b. Identification of MW Polyomavirus, a novel polyomavirus in human stool. J Virol. 86: 10321-10326. doi: 10.1128/JVI.01210-12

Smith, A. E., and Helenius, A. 2004. How viruses enter animal cells. Science 304: 237-242. doi: 10.1126/science. 1094823

Soeda, E., Arrand , J. R., Smolar, N., Walsh, J. F., and Griffin, B. E.1980. Coding potential and regulatory signals of the polyomavirus genome. Nature 283: 445-453. PMID: 6243401

Spurgeon, M. E., and Lambert, P. F. 2013. Merkel cell polyomavirus: a newly discovered human virus with oncogenic potential. Virology 435: 118-130. doi: 10.1016/j.virol.2012.09.029 
Stehle, T., and Harrison, S. C. 1996. Crystal structures of murine polyomavirus in complex with straight-chain and branched-chain sialyloligosaccharide receptor fragments. Structure 4: 183-194. PMID: 8805524

Stehle, T., and Harrison, S. C. 1997. High-resolution structure of a polyomavirus VP1oligosaccharide complex: implications for assembly and receptor binding. EMBO J. 16: 5139-5148. doi: 10.1093/emboj/16.16.5139

Stehle, T., Yan, Y., Benjamin, T. L., and Harrison, S. C. 1994. Structure of murine polyomavirus complexed with an oligosaccharide receptor fragment. Nature 369: 160 163. doi: $10.1038 / 369160 \mathrm{a} 0$

Stillman, B. 1989. Initiation of eukaryotic DNA replication in vitro. Annu. Rev. Cell Biol. 5: 197-245. doi: 10.1146/annurev.cb.05.110189.001213

Stolt, A., Sasnauskas, K., Koskela, P., Lehtinen, M., and Dillner, J. 2003: Seroepidemiology of the human polyomaviruses. J Gen.Virol. 84: 1499-1504. doi: 10.1099/vir.0.18842-0

Stroh, L. J, Neu, U., Blaum, B. S., Buch, M. H. C., Garcea, R. L., and Stehle, T. 2014. Structure analysis of the major capsid proteins of human Polyomaviruses 6 and 7 reveals an obstructed sialic acid binding site. J Virol. 88: 10831-10839. doi: 10.1128/JVI.01084-14

Sullivan, C. S., and Pipas, J. M. 2002. T antigens of simian virus 40: molecular chaperons for viral replication and tumorigenesis. Microbiol. Mol. Biol. Rev. 66: 179-202. PMID: 12040123

Suzuki, T., Orba, Y., Okada, Y., Sunden, Y., Kimura, T., Tanaka, S., Nagashima, K., Hall, W. W., and Sawa, H. 2010. The human Polyoma JC virus agnoprotein acts as a viroporin. PLoS Pathog. 6: e1000801. doi:10.1371/journal.ppat.1000801

Suzuki, T., Semba, S., Sunden, Y., Orba, Y., Kobayashi, S., Nagashima, K., Kimura, T., Hasegawa, H., and Sawa, H. 2012. Role of JC virus agnoprotein in virion formation. Microbiol. Immunol. 56: 639-646. doi: 10.1111/j.1348-0421.2012.00484.x

Takasaka, T., Goya, N., Tokumoto, T., Tanabe, K., Toma, H., Ogawa, Y., Hokama, S., Momose, A., Funyu, T., Fujioka, T., Omori, S., Akiyama, H., Qin Chen, Q., Huai-Ying Zheng, H- 
Y., Ohta, N., Kitamura, T., and Yogo, Y. 2004. Subtypes of BK virus prevalent in Japan and variation in their transcriptional control region. J Gen. Virol. 85: 2821-2827. doi: 10.1099/vir.0.80363-0

Thomsen, P., Roepstorff, K., Stahlhut, M., and van Deurs, B. 2002. Caveolae are highly immobile plasma membrane microdomains, which are not involved in constitutive endocytic trafficking. Mol. Biol. Cell. 13: 238-250. doi: 10.1091/mbc.01-06-0317

Trofe, J., Cavallo, T., First, M., Weiskittel, P., Peddi, V., and Roy Chaudhury, P. 2002. Polyomavirus in kidney and kidney-pancreas transplantation: a defined protocol for immunosuppression reduction and histological monitoring. Transplant. Proc. 34: 17881789. PMID: 12176577

Tsai, B., Gilbert, J. M., Stehle, T., Lencer, W., Benjamin, T. L., and Rapoport, T. A. 2003. Gangliosides are receptors for murine polyoma virus and SV40. EMBO J 22: 4346-4355. doi: $10.1093 / \mathrm{emboj} / \mathrm{cdg} 439$

Tsang, S. H., Wang, X., Li, J., Buck, C. B., and You, J. 2014. Host DNA damage response factors localize to Merkel Cell Polyomavirus DNA replication sites to support efficient viral DNA replication. J Virol. 88: 3285-3297. doi:10.1128/JVI.03656-13

Waga, S., and Stillman, B. 1994. Anatomy of a DNA replication fork revealed by reconstitution of SV40 DNA replication in vitro. Nature 369: 207-212. doi: 10.1038/369207a0

Wente, S. R., and Rout, M. P. 2010. The nuclear pore complex and nuclear transport, Cold Spring Harb. Perspect. Biol. 2: a000562. doi: 10.1101/cshperspect.a000562

Yu, G., Greninger, A. L., Isa, P., Phan, T. G., Martinez, M. A., De La Luz Sanche, M., Contreras, J. F., Santos-Preciado, J. I., Parsonnet, J., Miller, S., DeRisi, J. L., Delwart, E., Arias, C. F., and Chiu, C. Y. 2012. Discovery of a novel polyomavirus in acute diarrheal samples from children. PLoS One 7: e49449. doi:10.1371/journal.pone.0049449 
Fable 1: Human polyomaviruses, disease associations, cellular receptor/co-receptors andentry mechanism

\begin{tabular}{|c|c|c|c|c|c|}
\hline $\begin{array}{l}\text { St. } \\
\text { No. }\end{array}$ & Virus Name & Abbreviations & Disease associations & $\begin{array}{c}\text { Receptor(s)t } \\
\text { Co-receptor(s) } \\
\text { (entry } \\
\text { mechanism) } \\
\end{array}$ & References $^{2}$ \\
\hline 4 & BK polyomavirus & BKPyV & $\begin{array}{l}\text { Hemorrhagic eystitis } \\
\text { and Nephropathy }\end{array}$ & $\begin{array}{l}\text { Gangliosides } \\
\text { GD1b, GT1b } \\
\text { (caveolin- } \\
\text { mediated } \\
\text { endocytosis) }\end{array}$ & $\begin{array}{l}\text { Dugan et al } \\
(2005) ; \\
\text { Low et al } \\
(2006)\end{array}$ \\
\hline$z$ & IC pelyomavirus & ICPyV & $\begin{array}{l}\text { Progressive Multifoeat } \\
\text { Leucoencephalopathy } \\
\text { (PML) }\end{array}$ & $\begin{array}{l}\mathrm{LSTc} / 5-\mathrm{HT}_{z} \\
\text { (clathrin- } \\
\text { mediated } \\
\text { endocytosis) }\end{array}$ & $\begin{array}{l}\text { Liu et al } \\
\text { (1998); } \\
\text { Assetta et al } \\
(2013)\end{array}$ \\
\hline 3 & KI polyomavirus & KIPyV & $\begin{array}{l}\text { Respiratory symptoms } \\
(?)\end{array}$ & Not Known & - \\
\hline 4 & WU polyomavirus & WUPy & $\begin{array}{l}\text { Respiratory symptoms } \\
(?)\end{array}$ & Not Known & - \\
\hline 5 & $\begin{array}{l}\text { Aerkelcell } \\
\text { polyomavirus }\end{array}$ & MCPyV & Merkel cell carcinoma & $\begin{array}{l}\text { Heparan } \\
\text { sulfate/Sialyted } \\
\text { glyean }\end{array}$ & $\begin{array}{l}\text { Sehowalter } \\
\text { et al (2011); } \\
\text { Netet al } \\
(2012)\end{array}$ \\
\hline 6 & $\begin{array}{l}\text { Human } \\
\text { polyomavirus } 6\end{array}$ & HPyV6 & $\begin{array}{l}\text { Squamous cell } \\
\text { earcinoma (?) } \\
\text { Keratoacanthoma (?) }\end{array}$ & Not Known & - \\
\hline 7 & $\begin{array}{l}\text { Human } \\
\text { polyomavirus } 7\end{array}$ & HPyV7 & $\begin{array}{l}\text { Pruritic rash (?), } \\
\text { thymoma (?) }\end{array}$ & Not Known & - \\
\hline 8 & $\begin{array}{l}\text { Trichodysplasia } \\
\text { Spinulosa associated } \\
\text { polyomavirus }\end{array}$ & TSPyV & $\begin{array}{l}\text { Trichodysplasia } \\
\text { Spinulosa }\end{array}$ & Not Known & - \\
\hline 9 & \begin{tabular}{|l|} 
Human \\
polyomavirus 9 \\
\end{tabular} & HPyVg & Not Known & Not Known & - \\
\hline 10 & AW polyomavirus & MWPyV & Not Known & Not Known & - \\
\hline 11 & STL polyomavirus & STLPyV & Not Known & Not Known & - \\
\hline 12 & $\begin{array}{l}\text { Human } \\
\text { polyomavirus } 12\end{array}$ & HPyV12 & Not Known & Not Known & - \\
\hline 13 & $\begin{array}{l}\text { New Jersey } \\
\text { pelyomavirus }\end{array}$ & NJPyV & Vaseular myopathy (?) & Not Known & - \\
\hline
\end{tabular}

a. References reporting receptors and co-receptors 


\section{Figure Captions}

Figure 1. Gangliosides involved in polyomavirus binding. The general structural organization is depicted at the left. GM1, mono-sialotetrahexosylganglioside 1.

Figure 2. Receptor-mediated endocytosis and intracellular trafficking to endoplasmic reticulum (ER) in polyomaviruses. Sialylated glycans, MHC I and gangliosides on cell surfaces bind to and facilitate entry of $\mathrm{SV} 40, \mathrm{mPyV}, \mathrm{BKPyV}$, whereas $\mathrm{JCPyV}$ require $\mathrm{LSTc}$ and $5-\mathrm{HT}_{2}$ for its attachment and entry respectively. MCPyV require primarily glycosaminoglycans and also ganglisides. SV40, mPyV and BKPyV are internalized through caveosomes that traffic through the cytoplasm, using microtubule network, to late endosome and finaly delivered to ER. JCPyV is internalized through clathrin-coated vesicles. Within the ER lumen SV40, BK/JC PyVs interact with ERp57 and PDI, a process required for the partial disassembly of viral capsids, and are then retrotranslocated to the cytoplasm via ER transmembrane proteins Derlin1 and SelL1. Murine mPyV interact with ERp29 and require Derlin2 for its exit. LSTc, sialyllacto-N-tetraose c; GAG, glycosaminoglycan; 5-HT2,5-hydroxytryptamine

Figure 3. Mechanism of nuclear entry in SV40/BKPyV/JCPyV. ONM, Outer nuclear membrane; INM, Inner nuclear membrane; NPC, Nuclear pore complex; IMP, Importin. 
Table I: Human polyomaviruses, disease associations, cellular receptor/co-receptors and entry mechanism

\begin{tabular}{|c|c|c|c|c|c|}
\hline $\begin{array}{l}\text { Sl. } \\
\text { No. }\end{array}$ & Virus Name & Abbreviations & Disease associations & $\begin{array}{c}\text { Receptor(s)/Co-receptor(s) } \\
\text { (entry mechanism) }\end{array}$ & References $^{\mathrm{a}}$ \\
\hline 1 & BK polyomavirus & $\mathrm{BKPyV}$ & $\begin{array}{l}\text { Hemorrhagic cystitis and } \\
\text { Nephropathy }\end{array}$ & $\begin{array}{l}\text { Gangliosides GD1b, GT1b } \\
\text { (caveolin-mediated endocytosis) }\end{array}$ & $\begin{array}{l}\text { Dugan et al (2005) } \\
\text { Low et al (2006) }\end{array}$ \\
\hline 2 & JC polyomavirus & JCPyV & $\begin{array}{l}\text { Progressive Multifocal } \\
\text { Leucoencephalopathy (PML) }\end{array}$ & $\begin{array}{l}\mathrm{LSTc} / 5-\mathrm{HT}_{2} \\
\text { (clathrin-mediated endocytosis) }\end{array}$ & $\begin{array}{l}\text { Liu et al (1998) } \\
\text { Assetta et al (2013) }\end{array}$ \\
\hline 3 & KI polyomavirus & KIPyV & Respiratory symptoms (?) & Not Known & - \\
\hline 4 & WU polyomavirus & WUPyV & Respiratory symptoms (?) & Not Known & - \\
\hline 5 & Merkel cell polyomavirus & MCPyV & Merkel cell carcinoma & Heparan sulfate/Sialyted glycan & $\begin{array}{l}\text { Schowalter et al (2011) } \\
\text { Neu et al (2012) }\end{array}$ \\
\hline 6 & Human polyomavirus 6 & HPyV6 & $\begin{array}{l}\text { Squamous cell carcinoma (?) } \\
\text { Keratoacanthoma (?) }\end{array}$ & Not Known & - \\
\hline 7 & Human polyomavirus 7 & HPyV7 & Pruritic rash (?), thymoma (?) & Not Known & - \\
\hline 8 & $\begin{array}{l}\text { Trichodysplasia Spinulosa- } \\
\text { associated polyomavirus }\end{array}$ & TSPyV & Trichodysplasia Spinulosa & Not Known & - \\
\hline 9 & Human polyomavirus 9 & HPyV9 & Not Known & Not Known & - \\
\hline 10 & MW polyomavirus & MWPyV & Not Known & Not Known & - \\
\hline 11 & STL polyomavirus & STLPyV & Not Known & Not Known & - \\
\hline 12 & Human polyomavirus 12 & HPyV12 & Not Known & Not Known & - \\
\hline 13 & New Jersey polyomavirus & NJPyV & Vascular myopathy (?) & Not Known & - \\
\hline
\end{tabular}

\section{a. References reporting receptors and co-receptors}




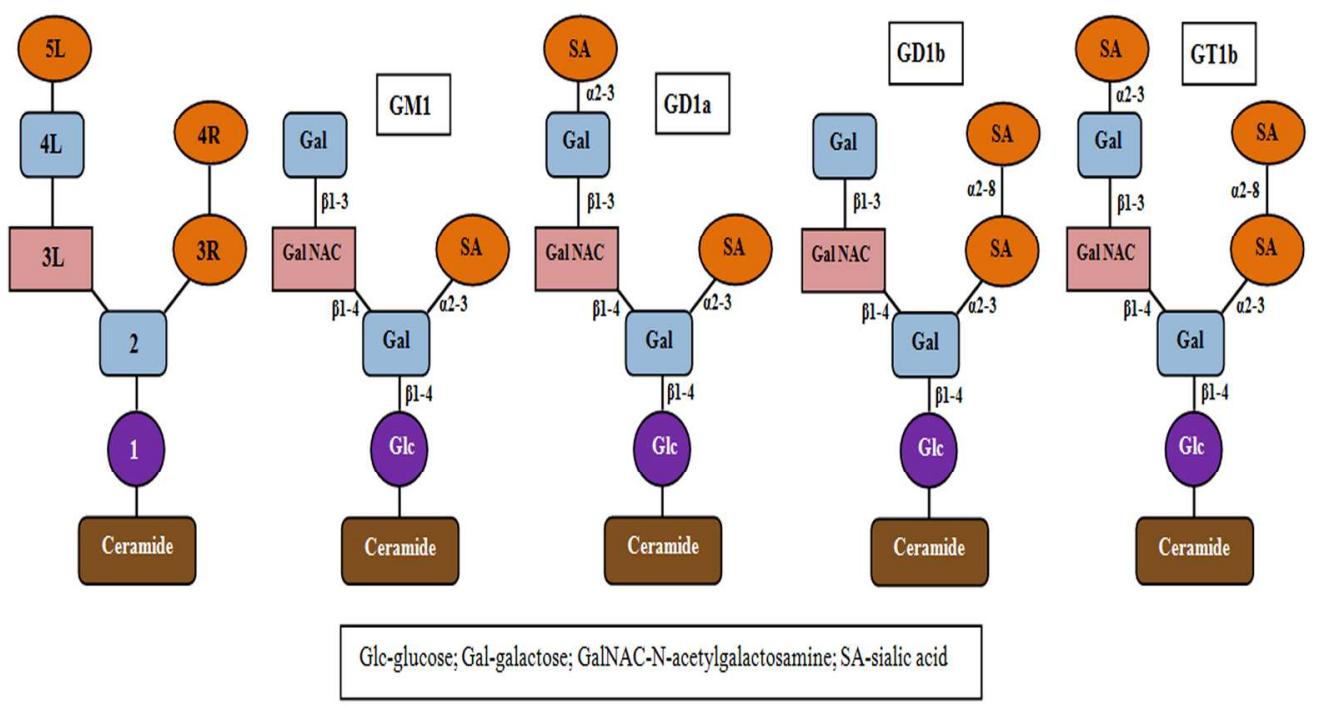

Figure 1. Gangliosides involved in polyomavirus binding. The general structural organization is depicted at the left. GM1, mono-sialotetrahexosylganglioside 1.

$$
635 \times 343 \mathrm{~mm}(96 \times 96 \mathrm{DPI})
$$




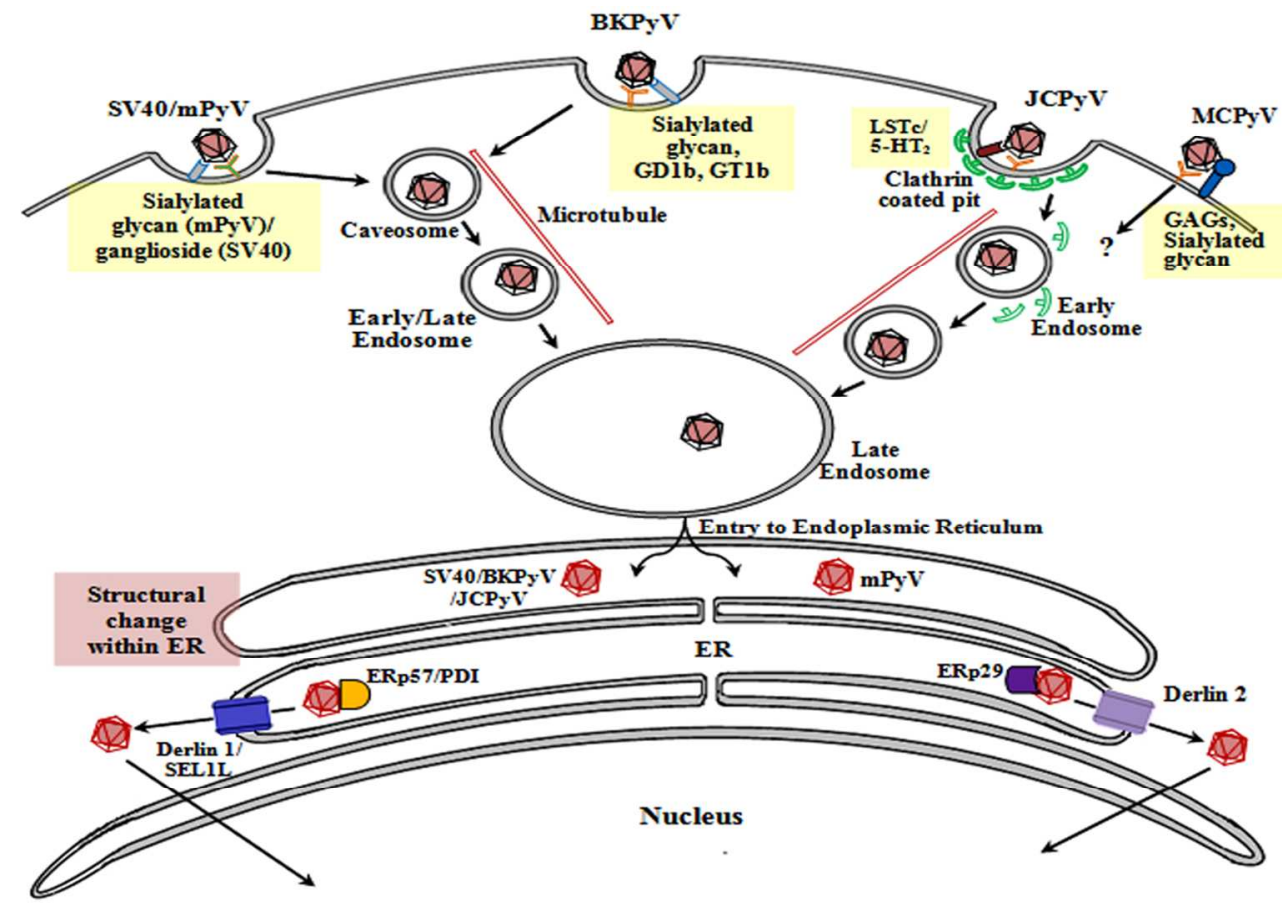

Figure 2. Receptor-mediated endocytosis and intracellular trafficking to endoplasmic reticulum (ER) in polyomaviruses. Sialylated glycans, MHC I and gangliosides on cell surfaces bind to and facilitate entry of SV40, mPyV, BKPyV, whereas JCPyV require LSTc and 5-HT2 for its attachment and entry respectively. $\mathrm{MCPyV}$ require primarily glycosaminoglycans and also ganglisides. SV40, mPyV and BKPyV are internalized through caveosomes that traffic through the cytoplasm, using microtubule network, to late endosome and finaly delivered to ER. JCPyV is internalized through clathrin-coated vesicles. Within the ER lumen SV40, BK/JC PyVs interact with ERp57 and PDI, a process required for the partial disassembly of viral capsids, and are then retrotranslocated to the cytoplasm via ER transmembrane proteins Derlin1 and SelL1. Murine mPyV interact with ERp29 and require Derlin2 for its exit.! + LSTc, sialyllacto-N-tetraose c; GAG, glycosaminoglycan; 5-HT2,5-hydroxytryptamine

$317 \times 222 \mathrm{~mm}(96 \times 96 \mathrm{DPI})$ 


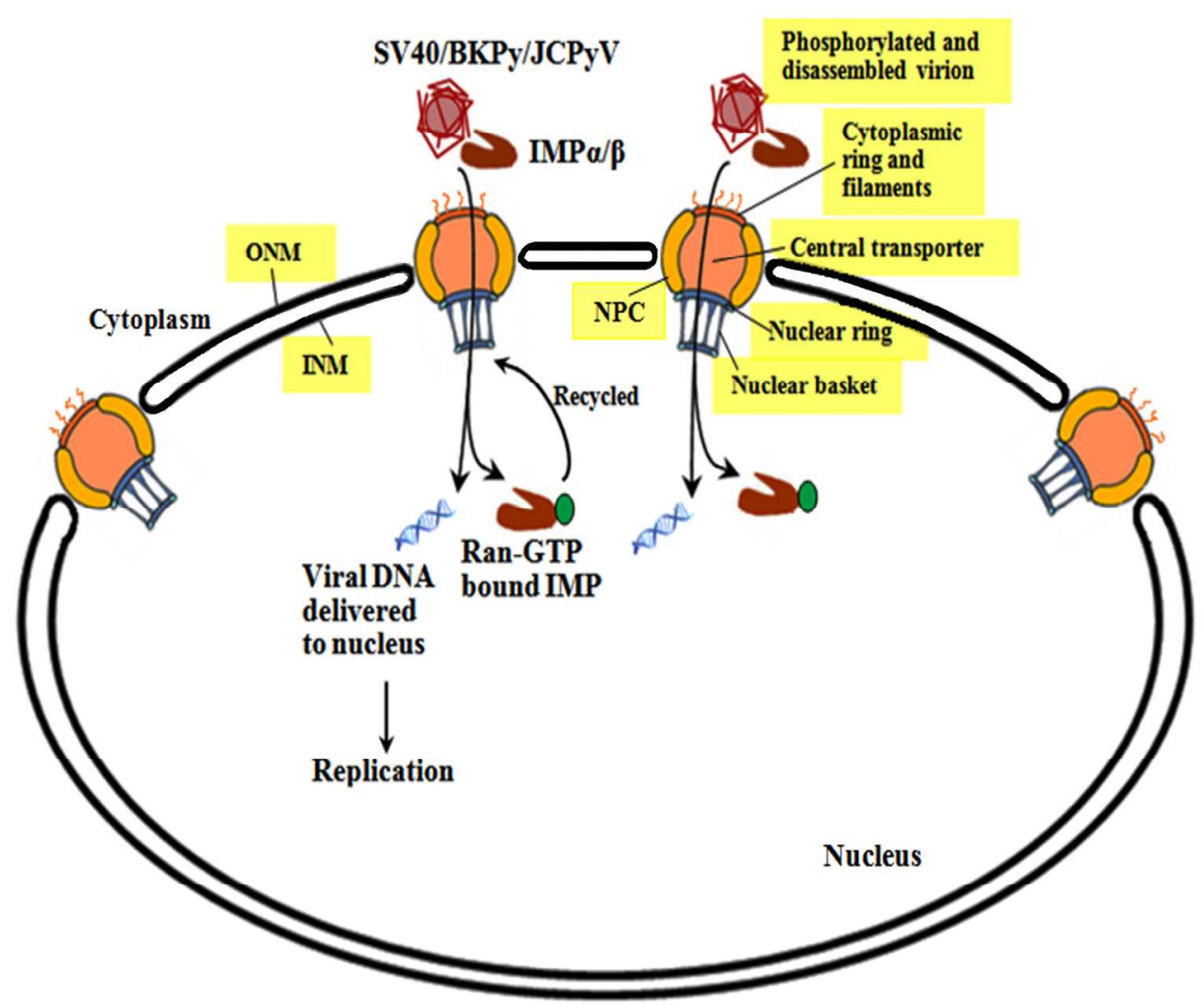

Figure 3. Mechanism of nuclear entry in SV40/BKPyV/JCPyV. ONM, Outer nuclear membrane; INM, Inner nuclear membrane; NPC, Nuclear pore complex; IMP, Importin.

$476 \times 387 \mathrm{~mm}(96 \times 96 \mathrm{DPI})$ 